\title{
Algae as a Source of Bioactive Compounds to Prevent the Develop- ment of Type 2 Diabetes Mellitus
}

\author{
Jelena B. Popović-Djordjević ${ }^{1}$, Jelena S. Katanić Stanković ${ }^{2}$, Vladimir Mihailović ${ }^{3}$, Antia G. \\ Pereiraa $^{4,5}$, Paula Garcia-Oliveira ${ }^{4,5}$, Miguel A. Prieto ${ }^{4, *}$, Jesus Simal-Gandara ${ }^{4, *}$
}

${ }^{1}$ University of Belgrade, Faculty of Agriculture, Department of Chemistry and Biochemistry, 11080 Belgrade, Serbia; ${ }^{2}$ University of Kragujevac, Institute for Information Technologies Kragujevac, Department of Science, 34000 Kragujevac, Serbia; ${ }^{3}$ University of Kragujevac, Faculty of Science, Department of Chemistry, 34000 Kragujevac, Serbia; ${ }^{4}$ Nutrition and Bromatology Group, Analytical and Food Chemistry Department, Faculty of Food Science and Technology, University of Vigo, Ourense Campus, E-32004Ourense, Spain; ${ }^{5}$ Centro de Investigação de Montanha (CIMO), Instituto Politécnico de Bragança, Campus de Santa Apolonia, 5300-253Bragança, Portugal

\begin{abstract}
Type 2 diabetes mellitus is a complicated metabolic disorder characterized by hyperglycemia and glucose intolerance. It is considered a new pandemic and its control involves numerous challenges. Although many of the measures are based on improving life habits, diet is also of vital importance due to bioactive compounds present in food. In this regard, several raw materials have been investigated whose bioactivities seem to slow the progression of this disease. Within these matrices, there are algae of importance, such as brown algae, showing to have beneficial effects on glycemic control. These pieces of evidence are increasing every day due to the development of cell or animal models, which lead to the conclusion that bioactive compounds may have direct effects on decreasing hyperglycemia, enhancing insulin secretion and preventing the formation of amyloid plaques.
\end{abstract}

Keywords: Diabetes mellitus, diabetes mellitus type 2, diet, algae, bioactive compounds, glycemic control.

\section{INTRODUCTION}

\subsection{Definition and Classification of Diabetes}

Diabetes mellitus (DM) is a complex metabolic disorder caused by the deficiency of insulin effects and characterized by a high level of blood glucose (hyperglycemia) [1]. The elevated levels of glucose in the blood can interfere with the metabolic pathways of proteins, carbohydrates, and fats in the organism causing severe complications [2]. Insulin, a peptide hormone, is produced by the $\beta$-Langerhans islet cells of the pancreas from precursors preproinsulin and proinsulin. In a normal physiological state, a higher blood glucose level (after a meal) triggers the release of insulin from the pancreas, which thereafter spark the metabolism of

\footnotetext{
*Address correspondence to these authors at the Nutrition and Bromatology Group, Analytical and Food Chemistry Department, Faculty of Food Science and Technology, University of Vigo, Ourense Campus, E-32004 Ourense, Spain; Tel: +34-654-694-616; Fax:+34-988-387060; E-mails: mprieto@uvigo.es (M.A.P), jsimal@uvigo.es (J.S.-G).
}

glucose in the liver, but also the elimination of glucose from the blood by muscle and adipose cells. All of the above lead to a reduction of high blood sugar concentration to ordinary values [2].

However, if the production and secretion of insulin (Fig. 1) are disrupted by various factors (genetic and/or environmental) or if the insulin action is injured, the or-ganism will be producing sugar through glycogen, pro-tein, and lipid metabolisms, leading to hyperglycemia. Besides, this state can increase protein catabolism and lipolysis and induce liver impairments manifested by metabolic acidosis and overproduction of ketone bodies [3, 4]. Additionally, in the state of diabetes, the following conditions can also develop: polyuria or forming high quantities of urine accompanied by glycosuria (high concentration of glucose in urine), polyphagia or increased appetite, polydipsia or higher need for liquids, possible weight loss, and severe consequences such as ketosis, acidosis, and coma. Hereby, there is an elevation of lipolysis and reduced possibility of amino acids entering the muscle tissues [1]. All above- 


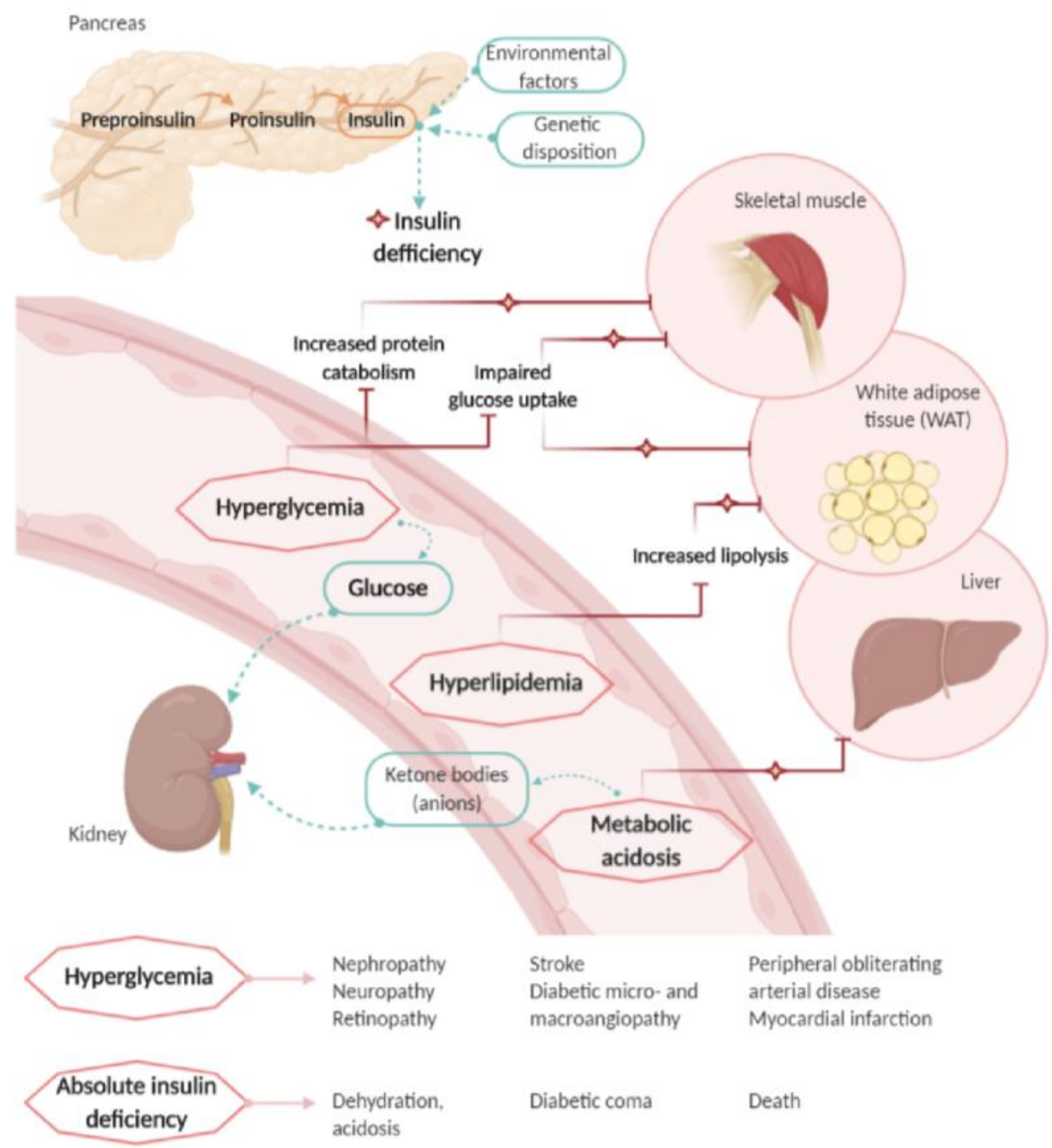

Fig. (1). Illustrative presentation of effects of insulin deficiency. Created in BioRender.com. (A higher resolution/-colour version of this figure is available in the electronic copy of the article).

mentioned factors, in particular, hyperglycemia, cause an increment of oxidative stress, boost inflammation processes, activate the polyol pathway and lead to long-term damage, micro- and macrovascular complications, severe failure of numerous organs (kidneys, eyes, brain, heart, cardiovascular system), and fatal outcome, death $[3,5]$.

Diabetes, as a debilitating, chronic disease, is threatening because of complications arising on different levels that can lead to serious acute and chronic manifestations. With severe problems that occur in diabetic pa- tients, their quality of life is significantly disturbed and life expectancy is reduced [6].

There are several types of diabetes, but two are the most prominent. Type 1 diabetes mellitus (T1DM), formerly known as insulin-dependent DM or "juvenile diabetes", represents an autoimmune disorder in which $\beta$-cells in the pancreatic islets are rapidly destroyed, causing impaired insulin secretion, which further leads to insulin deficiency in the organism [7, 8]. T1DM affects mostly children and adolescents and accounts for $3-5 \%$ of total cases [1]. The children with T1DM are 
inclined to develop ketoacidosis, so the essential therapy is based on insulin administration on a daily basis to control the glucose concentration in the blood [3].

On the other hand, type 2 diabetes mellitus (T2DM), formerly identified as non-insulin-dependent diabetes mellitus, is characteristic for adults. Generally, the incidence of T2DM increases in patients who are more than 30 years old [6]. T2DM occurs because of impaired insulin release from the pancreatic $\beta$-cells followed by insulin resistance (IR) in peripheral tissues (brain, liver, skeletal muscle, and adipose tissues). Because of IR, the secretion of insulin increases greatly, but also the hyperglycemia $[1,8]$.

Another type of diabetes, which receives more attention nowadays, is gestational diabetes (GDM). Conferring with the Centers for Disease Control and Prevention, it is deemed a category of diabetes that occurs first time during pregnancy [9]. The cause of this manifestation is still unknown. On a yearly level, around $10 \%$ of all pregnancies in the USA are affected by this type of diabetes [10]. It usually develops in middle pregnancy and may cause the development of chronic diabetes in the mother, as well as the baby.

Still, T2DM holds a devastating record affecting more than $90 \%$ of total diabetes cases in Western countries. Nowadays, there is an alarming upward trend of T2DM development in children [3]. The genetic predisposition, ethnicity, older age, unhealthy lifestyle, smoking, and bad dietary habits promote the probability of T2DM development. The initial stage in T2DM is indicated by hyperfunction of pancreatic $\beta$-cells, causing their dysfunction and promoting apoptosis [7]. It is interesting that years can pass before the presence of type 2 diabetes is properly diagnosed due to the lack of recognizing the symptoms of this disease. T2DM in patients, initially, does not require insulin treatment since the first symptoms could be monitored and prevented by a healthy diet, physical activity, lifestyle change in general, and using medication if necessary [6]. However, if there is a serious disturbance of $\beta$-cells activity, regular doses of insulin are of the greatest necessity so that the organism can survive a condition that is brought upon it [6]. Also, the IR acts in a disturbing manner on signaling pathways affecting all metabolic reactions connected to insulin activity, in addition to causing dysfunction of the endoplasmic reticulum, accumulation of lipids and development of an inflammation response [6].

Many pharmacological and non-pharmacological treatments are in use in T2DM therapy, but there is still no completely efficacious treatment of the DM causes. Patients are advised to change their lifestyle and diet, to reduce stress levels, and to monitor their condition. If that is not helpful, drug therapy is included, but this is still just focused on treating the symptoms of diabetes, not its cause [5]. The routine injection of insulin is the most common therapy, and also the administration of synthetic drugs. The antidiabetic drugs have different targets of actions, such as reducing the resistance of insulin, postponing the carbohydrate absorption, boosting the release of insulin, the sensitivity to insulin can be enhanced by drugs and some can act in the same way as insulin $[11,12]$. The therapies with antidiabetics are mostly considered to be lifelong, but many drugs are reported to exert quite serious side effects, moderate like nausea or diarrhea, weakness, weight gain, but also severe like haematuria, proteinuria, gastrointestinal disturbances, and cardiovascular mortality $[4,5,12]$. Therefore, the quest for new drug candidates with advanced antidiabetic properties and the absence of negative effects still continues. In this respect, medicinal plants, mushrooms, algae, and pure natural compounds may be used as safe alternatives with many benefits for human health, among which crucial are antidiabetic properties with various modes of action [6, 13-15].

\subsection{Considering Diabetes as a New Pandemic of the 21st Century}

World Health Organization (WHO) proclaimed diabetes as an epidemic illness, and the unique non-infectious disease with such categorization [11]. Factors such as behavior, genetics and socioeconomics have a great impact on diabetes. The literature shows that the global burden of diabetes is on the rise $[16,17]$. According to the recent data, it was estimated that about 463 million adult people (age 20-79 years) worldwide were affected by diabetes in 2019 , which is four-fold higher compared to the number in the 1980 s [8]. It should be emphasized that nearly $50 \%$ of people with diabetes are not aware of the fact that they have diabetes [17]. Continuing this trend, the number of people with diabetes will increase over 600 million by $2040[11,17]$. Data related to the global burden of dia-betes, its prevalence and associated risks are summarized in Fig. (2).

The observation regarding the area of living and the county income suggests that higher prevalence is in urban rather than in rural areas, and in high-income than in low-income countries. Among adults with diabetes in 2019, nearly half of them lived in five nations: China, India, the USA, Pakistan and Brazil [18]. Looking by gender, the prevalence is higher in men compared to women [19]. In 2012, about 3.7 million deaths were associated with diabetes or glucose levels higher than 


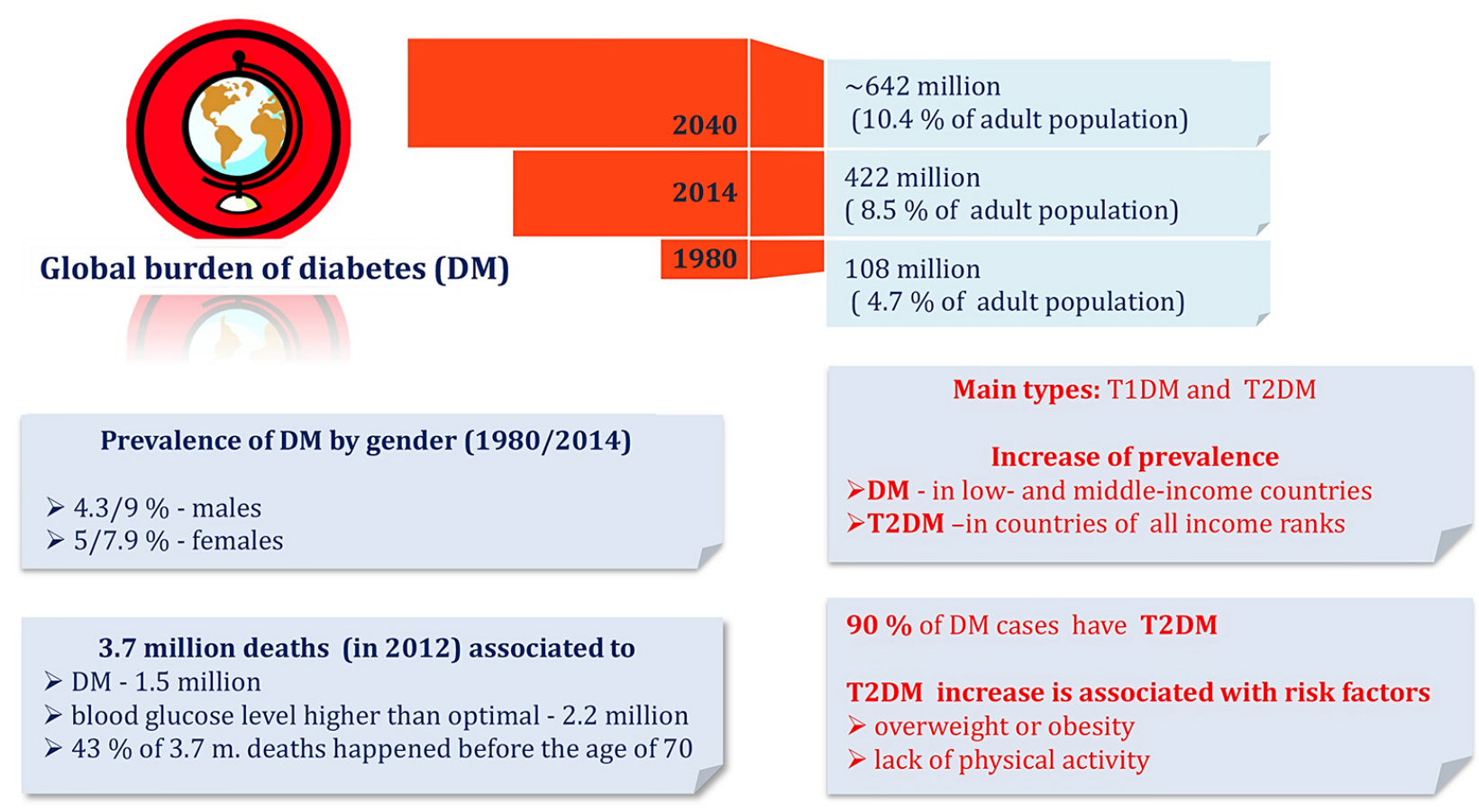

Fig. (2). Global burdens of DM. (A higher resolution/colour version of this figure is available in the electronic copy of the article).

optimal, and $43 \%$ of deaths occurred in people younger than 70 [5]. The latest figures show that about $11.3 \%$ of global deaths are due to diabetes, on a global level, and almost half of these deaths are people un-der 60 years of age [18].

Among the major types of this chronic disease, T2DM is the most prevalent, accounting for about $90 \%$ of people with diabetes $[3,11,20]$. Children and adolescents (aged under 20) are the most vulnerable groups with respect to T1DM. On the other hand, T2DM is diagnosed in adults $(>20)$, but there has been some evidence that it is increasing in some countries among children and adolescents [18]. Risk factors closely linked to the development of T2DM are obesity/overweight, lack of physical activity, smoking habits, excessive consumption of alcoholic beverages, ethnicity (South Asian, Afro-Caribbean, Hispanic), etc. [21]. Unlike for T2DM, genetic susceptibility and unknown environmental causes are risks for T1DM. Unfortunately, with the standard of living increasing, so is the prevalence of both diabetes types worldwide $[17,21,22]$.
Although DM is a chronic disorder, individuals with diabetes can lead a normal life at the same time, taking care that diabetes is under control. Lifestyle changes (changes in daily habits) and nutritional therapy are essential components of any diabetes control plan. Lifestyle changes can be an effective mode to control diabetes. Better blood sugarcontrol can slow the evolution of long-term compli-cations. Nutrition modification in people with diabetes is often very complex, and should take into considera-tion individual nutritional needs, cultural preferences and lifestyle. Often, the help of a skilled dietitian is crucial in ensuring the proper nutrition therapy. Changing the type and quantity of food intake can help people with diabetes to lose weight, improve control of blood sugar levels and lower blood cholesterol levels and blood pressure. Dietary practices differ from region to region, but socioeconomic status also has a great influence on diet habits. The main advice of diabetes experts is to reduce carbohydrate levels in diet along with reducing the fat intake and to use higher quality food ingredients [23]. A well-balanced diet should contain carbohydrates (preferably from grains, fruits, vegetables and low-fat milk), proteins, fats, suitable quantities of vitamins and minerals from natural food sources [24]. The usual days' meals and snacks should supply about 1,500-2,000 calories provided by carbohydrates, 
proteins and fats in approximate relation of 50, 20 and $30 \%$, respectively [25].

Besides proper nutrition, physical activity is also important for people with diabetes. Even people with long-term diabetes or its complications can benefit from exercise. The exercise improves the patients' cardiovascular condition and helps with weight loss, lowers blood pressure, improves lipid profiles, in some cases improves blood sugar control and leads to a better overall condition of the body. In some people, it can also prevent the development of T2DM [26, 27].

\subsection{Problems Arising from T2DM}

As a metabolic disorder, diabetes of any type is associated with different health problems and shorter life expectancy. Over time, elevated glucose levels may provoke both acute and chronic complications and development of eye diseases (retinopathy), cardiovascular diseases, chronic kidney disease, nerve and vascular damage and stroke blindness $[16,18]$. The risk of fetal death and other complications is increased in pregnancy if diabetes is not properly controlled $[18,27]$. In addition to adequate anti-diabetic therapy (both drug and nutrition), psychological adjustment to diabetes is equally important, as diabetes-related emotional distress may negatively influence glycemic control [28].

Economic and social impacts imposed by diabetes should not be neglected. For the treatment of diabetes and its complications, billions of dollars are spent every year [22]. This includes both direct (treatment of complications) and indirect (premature death, disability and other health complications) costs of the annual global health expenditures associated with the condition. The discrepancy between diabetes-related health expenditure and the number of people suffering from diabetes in countries of different income levels is notable. It is estimated that $95 \%$ of the global health expenditure on diabetes is allocated from the world's richest countries, North America (57\%), Europe (28\%) and Western Pacific (10\%) [29]. The mortality related to diabetes-related premature deaths $(90 \%)$ and all deaths due to diabetes $(87 \%)$ is the highest in low- and middle-income countries. The low rate of diabetes diagnosis and difficulties in acquiring the proper medicinal care in these countries are closely associated with such mortality outcomes [18].

Nonetheless, several trials have demonstrated that changes in lifestyle and pharmacology could postpone or prevent the development of T2DM. Additional studies showed that implementing lifestyle changes for diabetes prevention in primary medical care and other approaches such as remote support (phone, email,
DVD, and the Web), meal replacement, etc. might give satisfactory results. It is necessary to put effort at both national and international levels to identify persons that are at risk of diabetes, and systematically implement these interventions. Health education in schools, food policy, acts that promote early detection and intensive management of type 2 diabetes, as parts of social in-terventions should be promoted [30]. Regular control of metabolic parameters (glucose, HbA1c, lipids, blood pressure, body weight, and renal function), and the quality of life, are important factors in providing ef-fective outcome in diabetes and diabetes-related diseas-es management.

\section{MECHANISMS OF NATURAL PRODUCTS- BASED DIETS IN TREATING IR}

Considering the increase in the number of people with DM, it is necessary to investigate mechanisms to combat it. However, there are also several measures whose objective is to prevent the appearance of the dis-ease. IR may be a predictor of T2DM, so taking the measures to prevent this problem could reduce the number of patients with T2DM [31]. Basically, these measures focus on changes in diet and lifestyle, especially in the case of the aging population [32]. In this regard, increasing the consumption of plants and algae may be interesting, as they have considered effective tools for the prevention and control of T2DM [33]. In fact, leguminous plants, whole grains, vegetables, fruits, nuts and seeds, have been linked with inferior rates of obesity, hypertension, hyperlipidemia, cardiovascular mortality and cancer. Therefore, it is of great interest to study eating patterns [34]. Nevertheless, additional studies are still required to adequately comprehend the action of macronutrients and factors such as the amount in which they are present or the metabolic and genetic differences between persons. All of this makes it complicate to standardize a diet, requiring their monitoring.

Nowadays, there is a negative trend between high levels of glycemic index and consumption of saturated fatty acids and carbohydrates. In contrast, diets with a low content in carbohydrates and high content in proteins induce weight loss, but cause long-term metabolic damage [35]. Moreover, high-fat (especially saturated) diets have negative effects on insulin sensitivity and could contribute to the development of T2DM [36, 37]. In this regard, fiber and phytonutrient consumption, which are only present in plant foods, is remarkable. Different studies show that a high consumption of fiber $(>25 \mathrm{~g} /$ day in women and $>38 \mathrm{~g} /$ day in men) reduces the probability of developing T2DM by $20-30 \%$, observing a higher effect when con- 
suming large amounts of whole grains and insoluble cereal fibers, since they do not significantly affect postprandial glucose responses. This would not happen with fruits and vegetables because they contain soluble and, therefore, digestible fibers [38]. However, these fermentable fibers give rise to short-chain fatty acids that increase glucose response and insulin signaling and sensitivity [39]. Regarding cereals, their fibers prevent the absorption of proteins, regulating the metabolism of amino acids [38]. Moreover, fibers have a satiating effect, which leads to weight loss and conse-quent reduction in IR [40]. IR begins in the hypothala-mus, creating an imbalance of satiety and hunger sig-nals. This imbalance causes an excessive increase in calorie consumption, compromising the storage of the excess of fat, which can have a noteworthy role in the control of IR [41]. Thus, satiety is important to manage IR.

Another interesting mechanism to prevent T2DM is the promotion of healthy body weight since visceral obesity (not subcutaneous) leads to increased IR and excessive accumulation of lipids in the liver, augmenting the risk of developing the disease. The accumulation of lipids can result in impaired insulin signaling or inflammation, which entails deterioration of the action of insulin due to the action of macrophages. In the case of subcutaneous fat, this does not happen since it prevents the fat from reaching the liver [42]. In conclusion, to improve metabolic parameters of IR it is preferable to maintain a negative energy balance better than maintaining a stable lower weight [43].

However, obesity is also associated with variations in the intestinal microbiota, which are potential contributors to metabolic diseases. In this regard, high-weight individuals show an increase in Firmicutes and Actinobacteria and a decrease in Bacteroidetes groups. These changes in the intestinal microbiota caused alterations in the intestinal permeability, which lead to greater activation of the inflammatory pathways and impaired insulin signaling. Specifically, a reduction in insulin receptor phosphorylation, insulin receptor substrate (IRS) and protein kinase B (Akt) was observed, while phosphorylation IRS-1 serine inhibitory was increased. Therefore, the modification of the intestinal microbiota gives rise to diverse signaling activations and alterations, which can be an attractive option for the management of obesity and T2DM [44]. Several genera have been described to be positively related with T2DM, among them Ruminococcus, Fusobacterium, and Blautia, whereas the genera Bifidobacterium, Bacteroides, Faecalibacterium, Akkermansia and Roseburia were negatively associated with T2DM
[45]. Therefore, knowing the role of the human gut microbiota in obesity and T2DM is a priority [46].

Exposure to certain types of compounds also generates IR, such as streptozotocin (a nitrosamine-related compound) and nitrosamines. The last are metabolites with a high presence in processed foods and whose chronic exposure prompts to IR and may progress to T2DM and other diseases, like non-alcoholic steatohepatitis and Alzheimer's disease. Thus, it is crucial to enhance the detection and decrease exposure to nitrosamines [47]. This can happen, for example, with the consumption of red meat which will also have heme iron [48]. High levels of iron in the diet are also an important factor in T2DM, since this compound has a direct and causal role in the pathogenesis of the disease, interceded by $\beta$-cell insufficiency and IR. Other adverse effects are related to insulin secretion and sensitivity, as well as adipokine levels and metabolic flexibility [49]. The scientific evidence indicates the great importance of iron in the diabetic condition since it influences the risk of developing the disease and the risk of suffering complications of the disease in an advanced stage [50]. However, although biomarkers of the iron metabolism pathway related to the appearance of DM are known, the underlying mechanisms are not yet discovered. Plasma levels of ferritin and TSAT are strongly related to various indicators of IR in young and healthy individuals. The weakest relationship has been observed with the indicators of short and longterm glucose controls. Therefore, iron metabolism has a pronounced influence in IR, nonetheless has a minor influence on blood glucose levels, with inflammation and/or obesity playing a crucial role [51]. Insulin sensitivity decrease due to the modulation of the transcription and membrane expression/affinity of insulin receptor expression in hepatocytes, which produces changes in insulin-dependent gene expression. Thus, in people suffering from non-alcoholic fatty liver disease, a positive effect of iron depletion can be achieved with the help of increased insulin clearance and a decrease in IR [52].

It also has to be taken into account the development of advanced glycation end products (AGEs), formed due to non-enzymatic modification of proteins by reducing sugars. During aging, the formation of AGEs increases, being this growth faster in DM. In fact, AGEs are implied in the pathogenesis of diabetic vascular difficulties. The interaction between AGEs and its receptor has been proven to cause oxidative stress and inflammation, which are factors closely associated with IR and later in the progress of diabetes [53, 54]. To prevent IR and its consequences, different strategies can 
be applied with the common objective of limiting the accumulation and action of AGEs [55]. Moreover, several studies proved that AGEs also present negative effects on non-diabetic states, characterized by an increase in AGEs concentration and impaired glucose homeostasis. This effect encompasses activation of endoplasmic reticulum- and inflammatory-stress and repression of glucose transporter type 4 (GLUT4) expression [56]. Therefore, a diet with low content of AGEs may have less risk of developing T2DM [57]. Through control and limitation of AGEs intake, native oxidative defenses and insulin sensitivity may be preserved [58].

As conclusions, among the mechanisms to prevent IR, we found maintaining healthy body weights, eating patterns, diets with high content in fiber and phytonutrients, and decrease in saturated fats, advanced glycation end products, nitrosamines and heme iron as the most important ones [33].

\section{EMERGING BOTANICAL ADVANCES FOR TREATMENT AND PREVENTION OF T2DM}

As mentioned before, the control of a high blood glucose level after eating is the main goal in T2DM patients. For this purpose, a restrictive diet, physical activity, and pharmacological methods are employed. The reduction of carbohydrates' digestion and their bioavailability, stimulation of insulin release, reduction of IR, increasing sensitivity to insulin, and mimicking insulin function are some of the mechanisms in which antidiabetic drugs are involved [12]. Several of these drugs are derived from natural products, mainly from plants and microbes. A guanidine derivative, galegine, isolated from Galega officinalis L. (Fabaceae) possesses a clear antidiabetic effect and its chemical structure is relatively comparable to the antidiabetic drug metformin $[6,11]$. Pycnogenol is a case of a natural compound with antidiabetic properties obtained from Pinus pinaster Aiton (Pinaceae), which possesses $\alpha$-glucosidase inhibitory activity. Also, acarbose is presumably the most extensively used enzyme inhibitor for carbohydrate digestion obtained from microbial origin [6, 16]. Besides the historical and ethnopharmacological importance of medicinal plants in the use of treatment of T2DM, antidiabetic preparations of botanical origin still have significant value in the treatment of DM and its comorbidities. The research of botanical products with antidiabetic potential has been stimulated by the numerous side effects of the long-term use of oral hypoglycemic drugs, limited efficacy of existing medications and the development of health complications associated with unregulated hyperglycemia in T2DM patients $[6,8,16]$.
In vitro laboratory and preclinical studies, as well as several clinical studies in T2DM patients, reported that medicinal herbs, spices, food plants, and mushrooms had shown the potential to improve the condition of diabetes mellitus [14, 59-61]. In recent years, many research papers and reviews dealing with the role of antidiabetic potential of medicinal plants and their secondary metabolites, including clinical trials, have been published. The most studied plant species and plants with the greatest potential in therapy for T2DM referred to these studies and reviews were bitter melon (Momordica charantia L.), cinnamon (Cinnamomum cassia Siebold), aloe (Aloe barbadensis Mill), nettle (Utrica dioica), chamomile (Matricaria recutita L.), turmeric (Curcuma longa L.), "yerba mate" (Ilex paraguariensis A.St.-Hil.), green and black tea (Camellia sinensis (L.) Kuntze), fenugreek (Trigonella foenum-graecum L.), garlic (Allium sativum L.), and onion (Allium cepa L.) [3, 6, 62, 63]. The mechanisms of natural products from botanical sources for controlling glycemia include inhibition of $\alpha$-glucosidase and $\alpha$-amylase as targets for carbohydrate breakdown reduction and prevention of the glucose increase in plasma [64], influence on glucose uptake and glucose transporters, and regulation of insulin secretion $[6,61]$. It is also approved that some plant preparations improved metabolic abnormalities caused by diabetes such as advanced glycation end-product formation, free radical over-production, and oxidative stress [5].

According to Choudhury et al. [61], most of the highly effective plants possess multimodal activities on the control of T2DM. In Fig. (3) [73-85], some of the active principles of main medicinal plants with antidiabetic effects are summarized. Cinnamon has been considered as a nutraceutical for T2DM since 1990 . Numerous studies on animal models show that the consumption of cinnamon stimulates insulin secretion, enhancing the production of gut glucagonlike peptide 1 (GLP-1) and induces overexpression of GLUT4, which increases the glucose uptake in the myocytes and adipocytes. Moreover, cinnamon also possesses a preventive effect on complications of diabetes, mainly by lowering glycation end-product formation, thought high phenolic content with antioxidant effects $[6,65]$. Also, several mechanisms of hypoglycemic activity of $M$. charantia (bitter melon) have been proposed in different in vitro and in vivo studies. This plant increases adiponectin release, improves glucose uptake, and activates peroxisome proliferator-activated receptors $\alpha$ and $\gamma$, regulating lipid and glucose hemostasis, and control IR $[66,67]$. Seeds of fenugreek (T. foenum-graecum) are widely used as a herbal medicine for diabetes. In addition, relevant scientific studies reported its antidia- 

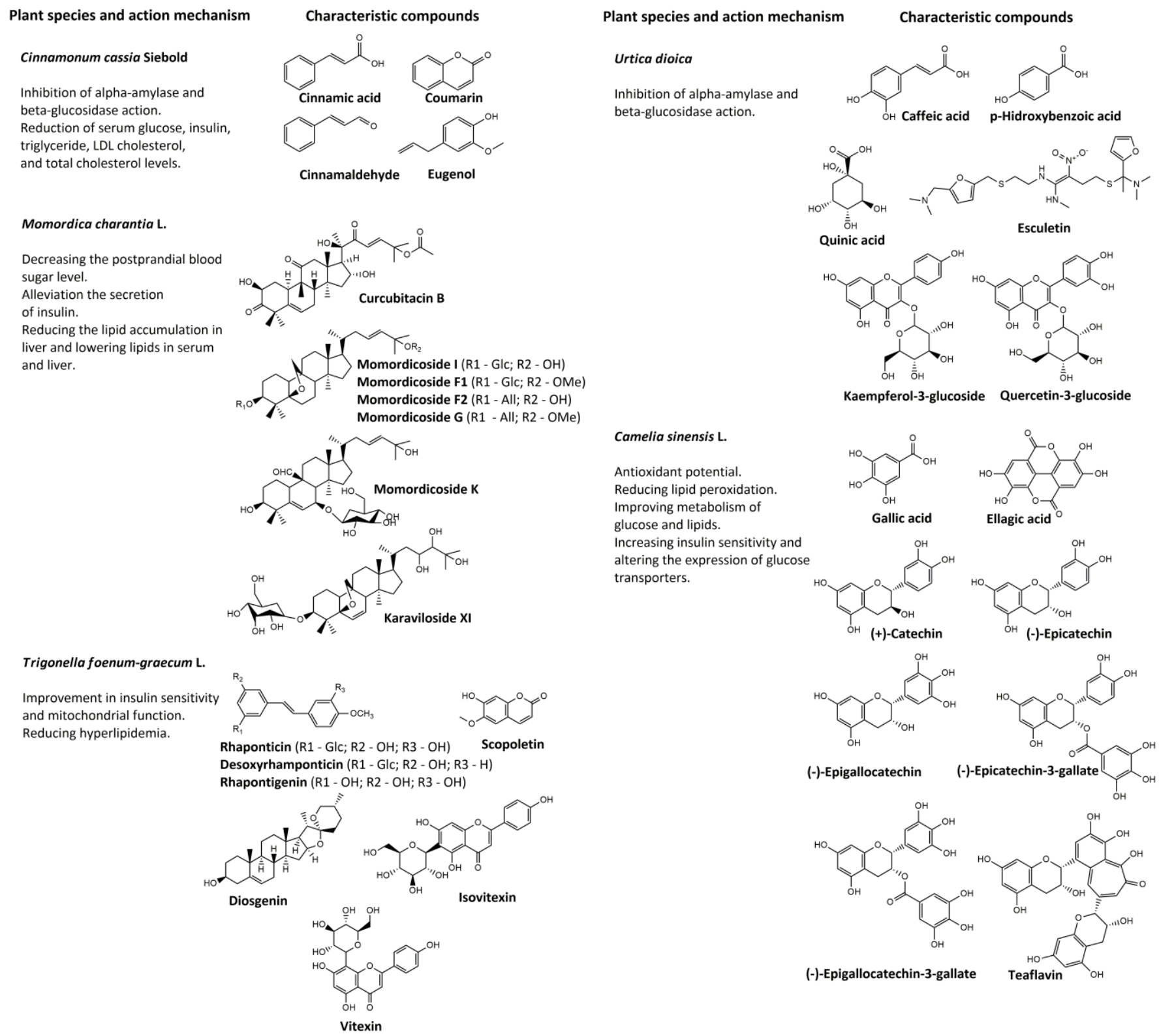

Fig. (3). Some of the active principles of main medicinal plants with antidiabetic effects [73-85].

betic effects by inhibiting $\alpha$-amylase and sucrase activities, stimulating insulin secretion, and increasing the number of insulin receptors [68]. Similar effects were reported for $U$. dioica [69-71]. Green and black tea $(C$. sinensis) is reported as an epigallocatechin gallate-en-riched plant with antidiabetic properties and positive ef-fects on diabetes complications [72]. Several mush-rooms are also reported as a potential class anti-dia-betic phytotherapeutics. Some medicinal and edible mushrooms showed the potential to reduce blood glu-cose levels, stimulate insulin secretion, improve in-sulin sensitivity, and reduce hepatic glucose output [60]. Considering mechanisms of action of botanical natural products in the treatment and control of T2DM, different polyherbal formulations with hypoglycemic activity were developed. The studies on diabet-ic animals showed that polyherbal formulations avail-able on the market possess antihyperglycemic effects and may improve endogenous antioxidant status [61].

There are several clinical studies, including plants, herbal formulations, or herbal extracts as antidiabeticagents. However, the number of in vitro screening and preclinical studies in animals of medicinal plants used 
for treating diabetes are more numerous compared with clinical trials. The major interest in research of plant species in the treatment of T2DM could be the increase of clinical trials and systematic reviews that can establish definitive conclusions for using a certain plant in antidiabetic therapy.

\section{ALGAE AS A NEW RESOURCE}

Nowadays, several authors have considered the algae as organisms not only of high ecological importance but also of economic significance [86]. In fact, the use of algae has undergone exponential growth and their application is already possible in various areas such as energy production, agriculture, food science, cosmeceutical and pharmacology [87]. One of its emerging applications is their use as a source of bioactive compounds with interesting biological properties at a medical level, including compounds for the prevention of T2DM. In this field, numerous investigations have been carried out using various species, especially with brown algae from the orders Laminariales and Fucales [88].

Among the compounds from algae for the prevention of T2DM, several could be highlighted, specially sugars. For example, alginate has demonstrated advantageous properties on glucose metabolism [89] and fucoidan has been reported to reduce $\alpha$-glucosidase activity, blood glucose and glycated hemoglobin and glucagon-like peptide- 1 in type 2 diabetes patients [90]. Other interesting compounds are phlorotannins, which present numerous antidiabetic activities, such as $\alpha$-glucosidase and $\alpha$-amylase inhibitory effect, modulation of glucose uptake effect in skeletal muscle, protein tyrosine phosphatase 1B (PTP1B) enzyme inhibition, improvement of insulin sensitivity in type 2 diabetic $\mathrm{db} / \mathrm{db}$ mice, and protective effect against DM complication [91]. Pigments also have beneficial properties. For example, fucoxanthin, present in brown algae, has displayed inhibitory activities against $\alpha$-amylase, $\alpha$-glucosidase and glucose oxidase in 3T3-L1 cells linked to T2DM [92] Chemical structures of algae' compounds with antidiabetic activity have been presented in Fig. (4). In this work, the species have been selected according to previous bibliographic research and their presence in the Iberian Peninsula.

\subsection{Brown Algae}

This group of algae present characteristic compounds, such as phlorotannins, fucoidans, fucoxanthin or fucosterols, whose antidiabetic properties have been evaluated and their importance has increased in recent years [93]. Within this group, multiple species have been investigated. Those available in the study region and that have been employed in several studies are shown below and have been summarized in Table $\mathbf{1}$.

\subsubsection{Ecklonia spp.}

The genus Ecklonia has been one of the most studied due to its extensive variety of therapeutic and health properties and biological activities, including antidiabetic, antioxidant, anti-inflammatory and hypolipidemic, among others [143]. Regarding antidiabetic activity, it is attributed to phenolic compounds, which have demonstrated inhibitory activity against two enzymes belonging to the gluconeogenesis pathway: phosphoenolpyruvate carboxykinase and glucose-6-phosphatase. This inhibition leads to the regulation of blood glucose levels, reducing the risk of hyperglycemia [97]. The phlorotannin eckol, considered one of the most representative compounds of this genus, has shown numerous biological activities, such as antioxidant, anti-inflammatory, antimicrobial, hepatoprotective or anti-hypertensive. According to this variety of properties, several studies have been focused in elucidating pharmacological potential [144].

\subsubsection{Laminaria spp.}

Within this genus, several species have been traditionally consumed in Asian cuisine, but the most prominent is Laminaria japonica, traditionally known as "kombu". This species contains a great number of compounds with confirmed biological activities and applications. According to the different scientific studies, the compounds responsible for the antidiabetic activity of Laminaria spp. are polysaccharides, butyl-isobutyl-phthalate and phenols. These compounds have been evaluated, both in vitro and in vivo. In fact, the Laminariaceae family was already used in traditional Chinese medicine for the treatment of DM [107].

\subsubsection{Saccharina spp.}

Like genus Laminaria, Sacharina spp. have been consumed in China and other oriental countries as traditional seafood products and also as medicine in traditional medicine. Saccharina japonica is one of the most studied algae within the genus, being rich in fucoidan, alginate, and laminarin [145]. Its antidiabetic properties have been associated with these polysaccharides since they augmented insulin levels, accumulation of glycogen in the liver and reduced the blood glucose level in diabetic mice, among other molecular mechanisms to palliate diabetic pathologies [146]. Although research is still preliminary and more studies should be conducted, this genus may have great potential for diabetes and obesity. 

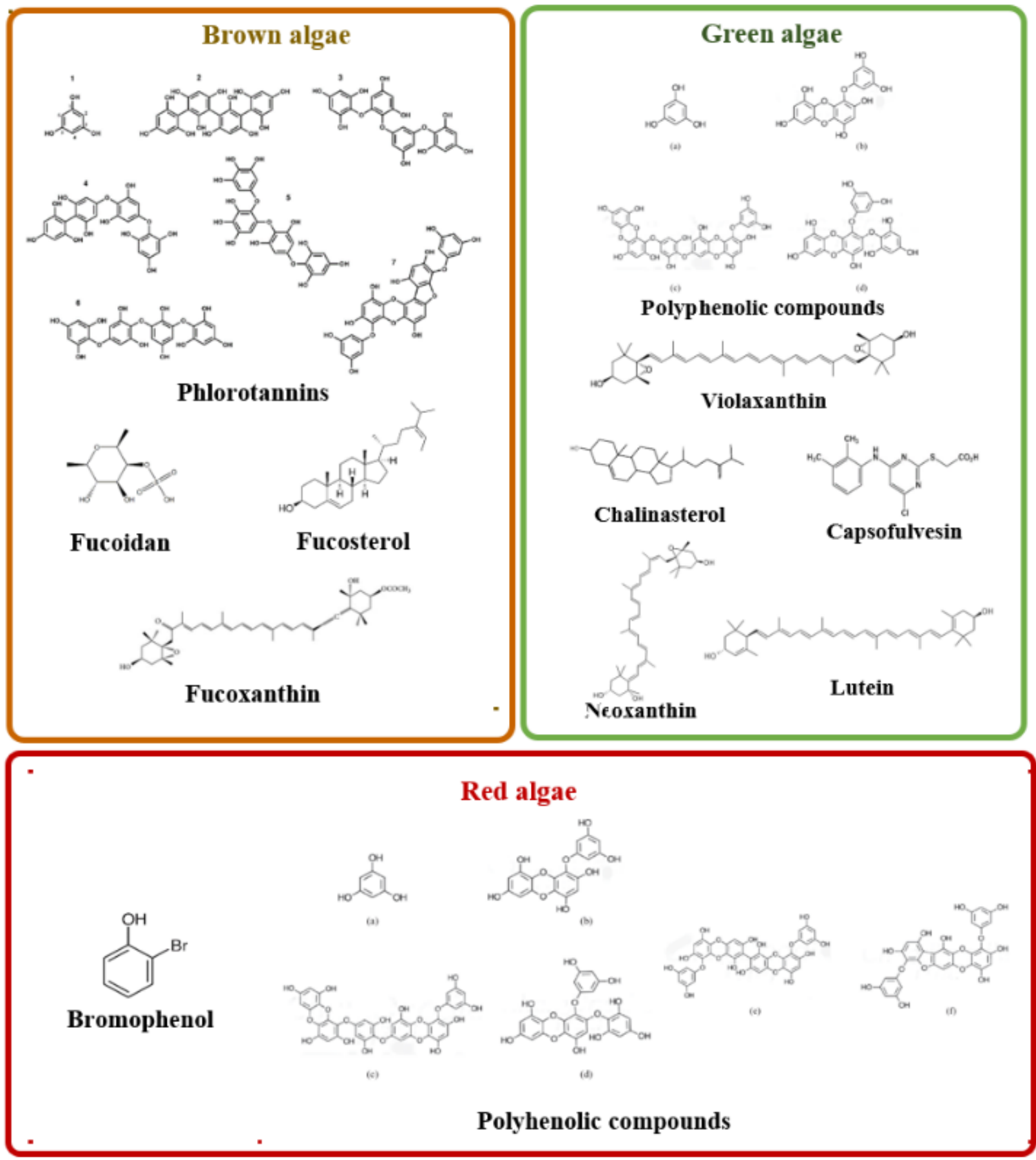

Fig. (4). Some of the active principles of algae with reported antidiabetic effects.

\subsubsection{Sargassum spp.}

Sargassum spp. contain numerous bioactive compounds, like phenolic compounds, sulphated polysaccharides, dietary fibers, carotenoids, etc. These compounds have been proven to exert various activities like antioxidant, anti-inflammatory, anti-tumor and also anti-diabetic, among others [147]. Among the species studied, Sargassum fusiforme, formerly known as Hizikia fusiformis, is one of the most relevant, but other species have shown antidiabetic properties. Other species of the same genus also have anti-diabetic properties. For example, Sargassum polycystum suppressed 
Table 1. Activity of the different species of brown algae genera mentioned and their compounds of interest.

\begin{tabular}{|c|c|c|c|c|c|}
\hline Algae & Compounds & $\begin{array}{l}\text { Extract / For- } \\
\text { mat }\end{array}$ & Main Outcomes & Test System & Ref. \\
\hline \multirow{6}{*}{ E. cava } & Phloroglucinol & C.E & $\begin{array}{l}\alpha \text {-glucosidase and } \alpha \square \text { amylase inhibition }\left(\mathrm{IC}_{50} 10.8\right. \\
\text { and } 124.9 \mu \mathrm{mol} / \mathrm{L} \text {, respectively) }\end{array}$ & In vitro & {$[94]$} \\
\hline & N.A & C.E & $\begin{array}{l}\alpha \text {-glucosidase and } \alpha \text {-amylase inhibition }\left(\mathrm{IC}_{50} 0.58 \text { and }\right. \\
0.35 \mathrm{mg} / \mathrm{mL} \text {, respectively) }\end{array}$ & In vitro & {$[95]$} \\
\hline & N.A & Supplement & $\begin{array}{l}\text { Treatment against high glucose-induced oxidative } \\
\text { stress }\end{array}$ & In vitro & {$[96]$} \\
\hline & Phloroglucinol & C.E & $\begin{array}{l}\text { Inhibiting hepatic gluconeogenesis via modulating the } \\
\text { AMP-activated protein kinase } \alpha \text { signaling pathway }\end{array}$ & In vivo (mice) & {$[97]$} \\
\hline & Dieckol & W & $\begin{array}{l}\text { Improving the glucose and lipid metabolism and an- } \\
\text { tioxidant enzymes }\end{array}$ & In vivo (mice) & {$[98]$} \\
\hline & N.A & Powder & $\begin{array}{l}\text { Hypoglycemic and hypolipidemic agent, prevents the } \\
\text { loss of } \beta \text {-cell mass resulting in the increase of insulin } \\
\text { secretary capacity }\end{array}$ & In vivo (mice) & {$[99]$} \\
\hline \multirow[b]{2}{*}{ E. maxima } & Fucoidan & W & $\alpha$-glucosidase inhibition $\left(\mathrm{IC}_{50} 0.27-0.31 \mathrm{mg} / \mathrm{mL}\right)$ & In vitro & {$[100]$} \\
\hline & $\begin{array}{l}\text { Eckol, dibenzo }[1,4] \\
\text { dioxine-2,4,7,9-tetraol, } \\
\text { phloroglucinol }\end{array}$ & EA & $\begin{array}{l}\alpha \text {-glucosidase inhibition }\left(\mathrm{IC}_{50} 11.16,33.69 \text { and } 1991\right. \\
\mu \mathrm{M} \text {, respectively) }\end{array}$ & In vitro & {$[101]$} \\
\hline \multirow[b]{2}{*}{ E. kurome } & Phlorotannins & C.E & $\begin{array}{l}\text { Inhibitory activities on carbohydrate-hydrolyzing en- } \\
\text { zymes and decreased postprandial blood glucose lev- } \\
\text { els }\end{array}$ & In vivo (mice) & {$[102]$} \\
\hline & N.A & Gametophytes & $\begin{array}{l}\text { Regulated metabolism by manipulating the balance } \\
\text { among cytokines, including interferon-gamma or } \\
\text { leptin, resulting in the down-regulation of blood glu- } \\
\text { cose }\end{array}$ & In vivo (mice) & {$[103]$} \\
\hline \multirow{3}{*}{ E. stolonifera } & Phlorofucofuroeckol-A & $\mathrm{EtOH}$ & $\begin{array}{l}\text { Advanced glycation end-products formation inhibition } \\
(40 \% \text { inhibition })\end{array}$ & In vitro & {$[104]$} \\
\hline & Polyphenols & $\mathrm{MeOH}$ & $\begin{array}{l}\text { Suppressed the increase in plasma glucose and lipid } \\
\text { peroxidation, inhibition of } \alpha \text {-glucosidase }\end{array}$ & In vivo (mice) & {$[105]$} \\
\hline & Phlorotannins & C.E & $\begin{array}{l}\text { PTP1B and } \alpha \text {-glucosidase inhibitory activity }\left(\mathrm{IC}_{50} \text { rang- }\right. \\
\text { ing between } 0.56 \text { to } 2.64 \mu \mathrm{M} \text { and } 1.37 \text { to } 6.13 \mu \mathrm{M} \text {., re- } \\
\text { spectively) }\end{array}$ & In vitro & {$[106]$} \\
\hline Laminaria spp. & N.A & W & $\begin{array}{l}\text { Effects on the postprandial blood glucose level in car- } \\
\text { bohydrate-loaded mice. }\end{array}$ & In vivo (mice) & {$[107]$} \\
\hline L. digitata & Alginates & W & Reduced blood glucose and insulin responses & In vivo (pigs) & {$[108]$} \\
\hline \multirow{7}{*}{ L. japonica } & BIP & C.E & $\alpha$-glucosidase inhibition $\left(\mathrm{IC}_{50} 35.00 \mu \mathrm{M}\right)$ & In vitro & {$[109]$} \\
\hline & BIP & EA & $\alpha$-glucosidase inhibition $\left(\mathrm{IC}_{50} 38.00 \mu \mathrm{M}\right)$ & $\begin{array}{l}\text { In vitro and in } \\
\text { vivo (mice) }\end{array}$ & {$[110]$} \\
\hline & BIP & EA & $\alpha$-glucosidase inhibition $\left(\mathrm{IC}_{50} 19.23 \mu \mathrm{M}\right)$ & In vitro & {$[111]$} \\
\hline & Pheophorbide A & $\mathrm{MeOH}$ & $\begin{array}{l}\text { Aldose reductase activity }\left(\mathrm{IC}_{50} 12.31 \mu \mathrm{M}\right) \text {, prevention } \\
\text { of diabetic complications }\end{array}$ & In vitro & {$[112]$} \\
\hline & Polyphenols & W & $\alpha$-glucosidase inhibition, attenuate muscle IR & $\begin{array}{l}\text { In vitro and in } \\
\text { vivo (mice) }\end{array}$ & {$[113]$} \\
\hline & Polysaccharides & W & $\begin{array}{l}\text { Reduced blood glucose and increased the levels of in- } \\
\text { sulin and amylin in serum }\end{array}$ & In vivo (mice) & {$[114]$} \\
\hline & Polysaccharides & W & $\begin{array}{l}\text { Prevented body-weight loss, increased serum insulin } \\
\text { levels }\end{array}$ & In vivo (mice) & {$[115]$} \\
\hline
\end{tabular}




\begin{tabular}{|c|c|c|c|c|c|}
\hline \multirow{6}{*}{ S. latissima } & $\begin{array}{l}\text { Pheophorbide-A, Pheophyt- } \\
\text { in-A }\end{array}$ & C.E & Aldose reductase inhibition $\left(\mathrm{IC}_{50} 12.31 \mu \mathrm{M}\right)$ & In vivo (mice) & {$[93]$} \\
\hline & - & Pellets & Lower bodyweight, lower HbAlc and insulin levels & In vivo (mice) & {$[116]$} \\
\hline & Fucoidan & Water & Stimulating the pancreatic release of insulin & In vivo & {$[117]$} \\
\hline & N.A & Power & $\begin{array}{l}\text { Influences glycemic control lowers blood lipids, and } \\
\text { increases antioxidant enzymes activity }\end{array}$ & $\begin{array}{l}\text { In vivo } \\
\text { (humans) }\end{array}$ & {$[118]$} \\
\hline & Phenolic compounds & Fermented & $\begin{array}{l}\alpha \text {-amylase and rat intestinal } \alpha \text {-glucosidase inhibition } \\
\left(\mathrm{IC}_{50} 0.98 \mu \mathrm{M}\right)\end{array}$ & In vivo (rats) & {$[119]$} \\
\hline & N.A & Powder & $\begin{array}{l}\text { Recovery of the the islet cell secreting function and re- } \\
\text { duction of the level of fasting blood glucose by an an- } \\
\text { tioxidant effect }\end{array}$ & In vivo (rats) & {$[120]$} \\
\hline \multirow{5}{*}{ S. fusiforme } & Fucosterol, fucoxanthin & $\mathrm{MeOH}$ & $\alpha$-glucosidase inhibition $\left(\mathrm{IC}_{50} 1.4 \mu \mathrm{M}\right)$ & In vitro & {$[121]$} \\
\hline & Phenols & $\begin{array}{l}\text { Vegetable ex- } \\
\text { tract with algae }\end{array}$ & $\begin{array}{l}\alpha \text {-glucosidase inhibition, weaker } \alpha \text {-amylase inhibition } \\
\text { activity }\end{array}$ & In vitro & {$[122]$} \\
\hline & Polyphenols & W & $\begin{array}{l}\alpha \text {-glucosidase inhibition, decreased tumor necrosis, at- } \\
\text { tenuated muscle } \mathrm{IR}\left(\mathrm{IC}_{50} 12 \mu \mathrm{M}\right)\end{array}$ & $\begin{array}{l}\text { In vitro and in } \\
\text { vivo (mice) }\end{array}$ & {$[113]$} \\
\hline & Fucoidan & $\mathrm{EtOH}$ & $\begin{array}{l}\text { Decreased fasting blood glucose, diet and water in- } \\
\text { take. Attenuation of pathological change in heart and } \\
\text { liver. Better liver function. Suppression of oxidative } \\
\text { stress. }\end{array}$ & In vivo (mice) & {$[123]$} \\
\hline & Polysaccharides & C.E & $\begin{array}{l}\text { Renal protection due to inhibition of the expression in- } \\
\text { flammatory compounds }\end{array}$ & In vivo (rats) & {$[124]$} \\
\hline $\begin{array}{l}\text { S. ringgol- } \\
\text { dianum }\end{array}$ & Phlorotannins & $\mathrm{MeOH}$ & $\begin{array}{l}\text { Decrease postprandial blood glucose level via inhibit- } \\
\text { ing } \alpha \text {-glucosidase }\left(\mathrm{IC}_{50}=0.12 \mathrm{mg} / \mathrm{mL}\right)\end{array}$ & $\begin{array}{l}\text { In vitro and in } \\
\text { vivo (mice) }\end{array}$ & {$[125]$} \\
\hline S. oligocystum & N.A & $\mathrm{EtOH}$ & $\begin{array}{l}\text { Decreased fasting blood glucose and HOMA-IR. Re- } \\
\text { generation and reconstitution of damaged pancreatic } \\
\beta \text {-cells }\end{array}$ & In vivo (rats) & {$[126]$} \\
\hline S. longiotom & N.A & EtOH & Effective hypoglycemic and hypolipidemic effect & In vivo (rats) & {$[127]$} \\
\hline S. duplicatum & Laminaran & EtOH & $\alpha$-glucosidase inhibition $\left(\mathrm{IC}_{50} 36.13 \mathrm{ppm}\right)$ & In vitro & {$[128]$} \\
\hline S. patens & Phloroglucinol & $\mathrm{EtOH}$ & $\begin{array}{l}\text { Inhibition of } \alpha \text {-glucosidase }\left(\mathrm{IC}_{50} 25.4 \mu \mathrm{g} / \mathrm{mL}\right) \text {, human } \\
\text { salivary and pancreatic } \alpha \text {-amylases }\left(\mathrm{IC}_{50} 3.2 \mu \mathrm{g} / \mathrm{mL}\right)\end{array}$ & In vivo (rats) & {$[129]$} \\
\hline S. polycystum & Pigments & EtOH, W & $\begin{array}{l}\text { Reduced blood glucose, HbA1c, triglyceride and } \\
\text { serum total cholesterol levels }\end{array}$ & In vivo (rat) & {$[130]$} \\
\hline S. hemiphyllum & Polyphenols, fucoxanthin & $\mathrm{EtOH}, \mathrm{AcO}, \mathrm{W}$ & $\begin{array}{l}\alpha \text {-amylase }\left(\mathrm{IC}_{50} 0.35 \mathrm{mg} / \mathrm{mL}\right), \mathrm{maltase}\left(\mathrm{IC}_{50} 0.09\right. \\
\mathrm{mg} / \mathrm{mL}) \text { and sucrase }\left(\mathrm{IC}_{50} 1.89 \mathrm{mg} / \mathrm{mL}\right) \text { inhibition }\end{array}$ & In vitro & {$[131]$} \\
\hline S. hystrix & N.A & $\mathrm{EtOH}$ & $\begin{array}{l}\text { Lowers the levels of preprandial and postprandial glu- } \\
\text { cose, prevents necrosis }\end{array}$ & In vivo (rat) & {$[132]$} \\
\hline S. binderi & N.A & W & $\alpha$-glucosidase inhibition $\left(\mathrm{IC}_{50} 6.39 \mathrm{mg} / \mathrm{mL}\right)$ & In vitro & {$[133]$} \\
\hline S. serratifolium & Plastoquinones & EtOH & $\begin{array}{l}\text { PTP1B and } \alpha \text {-glucosidase inhibition ( } \mathrm{IC}_{50} 1.83 \text { to } 7.04 \\
\text { and } 3.16 \text { to } 24.16 \mu \mathrm{g} / \mathrm{mL} \text {, respectively). }\end{array}$ & In vitro & {$[134]$} \\
\hline \multirow{5}{*}{ U. pinnatifida } & Phenols & C.E & $\begin{array}{l}\alpha \text {-glucosidase inhibition, weaker } \alpha \text {-amylase inhibition } \\
\text { activity }\end{array}$ & In vitro & {$[122]$} \\
\hline & Fucoxanthin & C.E & $\begin{array}{l}\text { Regulates mRNA expression of inflammatory adipocy- } \\
\text { tokines involved in IR }\end{array}$ & $\begin{array}{l}\text { In vitro and in } \\
\text { vivo (mice) }\end{array}$ & {$[135]$} \\
\hline & N.A & Dried & Reduced IR & In vivo (mice) & {$[136]$} \\
\hline & N.A & Dried & Reduces postprandial glucose concentration & $\begin{array}{l}\text { In vivo } \\
\text { (humans) }\end{array}$ & {$[137]$} \\
\hline & N.A & Dried & $\begin{array}{l}\text { Improves postprandialglucose homeostasis, reduces } \\
\text { glycemic excursions in prediabetes }\end{array}$ & $\begin{array}{l}\text { In vivo } \\
\text { (humans) }\end{array}$ & {$[138]$} \\
\hline
\end{tabular}

(Table 1) contd.... 


\begin{tabular}{|l|l|l|l|l|l|}
\hline & Fucoidan & C.E & $\begin{array}{l}\text { Suppresses adipocyte differentiation by inhibition of } \\
\text { inflammation-related cytokines }\end{array}$ & In vivo (mice) & [139] \\
\cline { 2 - 6 } & Fucoxanthin & Lipid extraction & $\begin{array}{l}\text { Increased Adrb3 and GLUT4 activities, with glucose } \\
\text { uptake into cells }\end{array}$ & In vivo (mice) & [140] \\
\cline { 2 - 6 } & Fucoxanthin & Lipid extraction & $\begin{array}{l}\text { Suppression of adipose tissue weight gain via up-regu- } \\
\text { lation of UCP-1 expression }\end{array}$ & $\begin{array}{l}\text { In vivo (rats } \\
\text { and mice) }\end{array}$ & [141] $]$ \\
\cline { 2 - 6 } & Fucoxanthin & C.E & $\begin{array}{l}\text { Inhibited the activities of HRAR, PTP1B, RLAR, as } \\
\text { well as AGEs formation. }\end{array}$ & In vivo (rat) & [142] \\
\hline
\end{tabular}

Compounds: Not Analyzed (N.A); Butyl-isobutyl-phthalate (BIP)

Solvent: Water (W); Ethanol (EtOH); Methanol (MeOH); Acetone (AcO); Ethyl Acetate (EA); Commercial extract (C.E)

Diabetes-related compounds and enzymes: Glycated hemoglobin (HbA1c); Homeostatic Model Assessment for Insulin Resistance (HOMA-IR); beta-3 adrenergic receptor (Adrb3); glucose transporter type 4 (GLUT4); Uncoupling protein one (UCP-1); Human recombinant aldose reductase (HRAR); Protein tyrosine phosphatase 1B (PTP1B); Rat lens aldose reductase (RLAR); Advanced glycation end-products (AGEs)

endocrine cell damage and necrotic cells, which have been attributed to antioxidant-related mechanisms [148]. According to these results it could be concluded that the extracts obtained with the e algae have curative properties on DM and may be considered as a new approach for the therapy of this disease.

\subsubsection{Undaria Pinnatifida}

This species, traditionally known as wakame, has been widely consumed [149]. It contains carbohydrates, proteins and many types of secondary metabolites, such as polyphenols. These compounds present strong biological activities, including antioxidant, anticancer, anti-inflammatory and anti-diabetes [150]. Several benefits have been described when used as supplements in the diet, including in glucose metabolism [151]. The main component responsible for this activity is alginate, which reduces glucose uptake in humans [152]. Other important components are the fucoidans, which regulate the blood glucose homeostasis, and also fucoxanthin. In particular, this carotenoid has been reported to inhibit PTP1B, human recombinant aldose reductase (HRAR), rat lens aldose reductase (RLAR), AGEs formation, regulates blood glucose and insulin levels, suppress monocyte chemoattractant protein-1 expression and promote beta-3 adrenergic receptor (Adrb3) and GLUT4 expression [150].

\subsection{Green Algae}

Although most antidiabetic compounds of algae are characteristic of brown algae, there are also other compounds with this activity present in green and red algae, such as polyphenolic compounds, dietary fibers or unsaturated fatty acids [153]. For example, the administration of Ulva rigida reduced blood glucose levels in diabetic rats submitted to streptozotocin and also complications related to the disease. In this study, the authors considered that phenolic compounds were involved in the anti-hyperglycemic effects observed [154]. Another example of green algae with anti-diabet- ic effects is Capsosiphon fulvescens. Capsofulvesin A, capsofulvesin B and chalinasterol from this species has demonstrated to inhibit alsode reductase [155]. Several studies have estimated the antidiabetic potential of Chlorella sp., which has inhibitory effects against AGEs production, especially pentosidine and N(6)-Carboxymethyllysine. In addition, carotenoids of this mi-croalgae, such as neoxanthin, lutein or violaxanthin, have shown strong antiglycation activity [156]. These properties and also the ability to inhibit $\alpha$-amylase and $\alpha$-glucosidase enzymes, have encouraged the develop-ment of different patents which use these species in the treatment of diabetes. For example, the biotechnology company Solazyme of the United States owns a patent that employs $C$. protothecoides for people with im-paired glucose tolerance and DM (US 8747834 B2). Other examples can be found in Table 2 .

\subsection{Red Algae}

Red algae also contain compounds of great interest for the treatment of T2DM. As an example, Odonthalia corymbifera' bromophenols show $\alpha$-glucosidase inhibition, with $\mathrm{IC}_{50}$ values varying between $0.098 \mu \mathrm{M}$ and $89.0 \mu \mathrm{M}$. Specifically, the compound bis(2,3-dibro-mo-4,5-dihydroxybenzyl) ether was the most potent. Similar results were observed in Symphyocladia latius-cula, with $\mathrm{IC}_{50}$ of $0.03 \mu \mathrm{M}$ for the same compounds, followed by 2,3,6tribromo-4,5-dihydroxybenzyl alco-hol with $\mathrm{IC}_{50}$ of 11.0 $\mu \mathrm{M}$ [169]. Another red alga, Poly-opes lancifolia, inhibited $\alpha$-glucosidase from Bacillus stearothermophilus and S. cerevisiae, with $\mathrm{IC}_{50}$ of 0.12 and $0.098 \mu \mathrm{M}$, respectively. The alga was also effective against rat intestinal maltase (and sucrose, with $\mathrm{IC}_{50}$ of 1.20 and $1.00 \mathrm{mM}$, respectively [170]. This activity is also present in other species such as Grateloupia elliptica [166], Rhodomela confervoides [171] or Laurencia similis [172]. Phenolic extracts obtained from Palmaria sp. showed inhibitory effects on $\alpha$-amylase enzyme [164]. Protein hydrolysates of the same 
Table 2. Activities of the other two big groups of algae.

\begin{tabular}{|c|c|c|c|c|c|}
\hline Algae & Compounds & Extract/Format & Main outcomes & $\begin{array}{l}\text { Test } \\
\text { system }\end{array}$ & Ref. \\
\hline \multicolumn{6}{|l|}{ Green algae } \\
\hline \multirow[t]{2}{*}{ C. lentillifera } & N.A & $\mathrm{EtOH}$ & $\begin{array}{l}\text { Reduction of DM-related enzymes activity, } \\
\text { increment of insulin secretion and glucose } \\
\text { uptake }\end{array}$ & In vitro & {$[157]$} \\
\hline & N.A & $\mathrm{EtOH}$ & $\begin{array}{l}\text { Regulated glucose uptake and homeostasis } \\
\text { via the PI3K/AKT pathway }\end{array}$ & $\begin{array}{l}\text { In vivo } \\
\text { (mice) }\end{array}$ & $\mid[158]$ \\
\hline C. sertularioides & N.A & $\mathrm{W}$ & $\begin{array}{l}\text { Hypoglycemic effect, alterations in the } \\
\text { lipid levels }\end{array}$ & $\begin{array}{l}\text { In vivo } \\
\text { (mice) }\end{array}$ & {$[159]$} \\
\hline C. macrophysa & Phenolic compounds & $\mathrm{EtOH}$ & $\begin{array}{l}\text { Reduction of dipeptidyl peptidase-IV and } \\
\alpha \text {-glucosidase enzyme activities. Inhibition } \\
\text { of cell death and inflammation }\end{array}$ & In vivo & {$[160]$} \\
\hline Chlorella spp. & Carotenoids, fatty acids & EA & Inhibition of the AGEs formation & In vitro & {$[156]$} \\
\hline C. zofingiensis & Astaxanthin & EA & $\begin{array}{l}\text { Antiglycative capacities (inhibition of } \\
\text { AGEs formation, glucose autoxidation, gly- } \\
\text { cation-induced protein oxidation) }\end{array}$ & In vitro & {$[161]$} \\
\hline$U$. rigida & N.A & Raw & Reduce plasma glucose levels & $\begin{array}{l}\text { In vivo } \\
\text { (rats) }\end{array}$ & {$[154]$} \\
\hline U. lactuca & Polysaccharides & $\mathrm{W}$ & Inhibition of enzymes & $\begin{array}{l}\text { In vivo } \\
\text { (rats) }\end{array}$ & {$[162]$} \\
\hline \multicolumn{6}{|l|}{ Red algae } \\
\hline \multirow{3}{*}{ P. palmata } & Proteins & $\mathrm{W}$ & Dipeptidyl peptidase IV inhibition & In vitro & {$[163]$} \\
\hline & Phenols & C.E & $\alpha$-amylase and $\alpha$-glucosidase inhibition & In vitro & {$[164]$} \\
\hline & N.A & Raw, dehydrated & $\begin{array}{l}\text { Lower bodyweight, } \mathrm{HbAlc} \text { and insulin lev- } \\
\text { els }\end{array}$ & $\begin{array}{l}\text { In vivo } \\
\text { (mice) }\end{array}$ & {$[116]$} \\
\hline R. confervoides & $\begin{array}{l}\text { 3,4-dibromo-5-(2-bromo-3,4-dihydroxy-6- } \\
\text { (ethoxymethyl)benzyl)benzene-1,2-diol }\end{array}$ & C.E & PTP1B inhibition & In vitro & {$[165]$} \\
\hline G. elliptica & 2,4,6-tribromophenol, 2,4-dibromophenol & C.E & $\begin{array}{l}\alpha \text {-glucosidase, sucrase and maltase inhibi- } \\
\text { tion }\end{array}$ & In vitro & {$[166]$} \\
\hline S. latiuscula & Bromophenols & C.E & Aldose reductase inhibition & In vitro & {$[167]$} \\
\hline G. amansii & N.A & Raw & $\begin{array}{l}\text { regulates plasma glucose and lipid levels } \\
\text { and prevents adipose tissue accumulation }\end{array}$ & $\begin{array}{l}\text { In vivo } \\
\text { (rats) }\end{array}$ & {$[168]$} \\
\hline
\end{tabular}

Compounds: Not Analyzed (N.A)

Solvent: Water (W); Ethanol (EtOH); Ethyl Acetate (EA); Commercial extract (C.E)

Diabetes-related compounds and enzymes: Glycated hemoglobin (HbA1c); Protein tyrosine phosphatase 1B (PTP1B); Advanced glycation end-products (AGEs); phosphatidylinositol 3-kinase/protein kinase B (PI3K/Akt)

alga also showed potential anti-diabetes properties [163]. Other examples can be seen in Table 2.

\section{FUTURE PERSPECTIVES}

The number of patients with diabetes continues to growth, being considered a pandemic. This trend involves a greater production of drugs to treat the disease and more research into methods to prevent it. This is a great interest, not only in terms of the health and wel- 1-being of the population, but also economically since the production of drugs is expensive. Persistent efforts and novel ideas are the driving force for the development of relevant drugs [173].

The approach to treat this disease has changed in the last few decades, especially at the dietary level. In the past, nutritional management of diabetes drastically eliminated all kinds of carbohydrate-rich foods [174], but nowadays, it is known that this disease is more 
linked to the quality of the carbohydrates and the fats ingested than to the proportion that they represent in the total of ingested macronutrients [175]. It is considered that the best dietary management of T2DM and IR consists of a balanced diet adapted to the associated pathologies of the patient. Dietary management of each patient must be carried out by the dietician in a detailed and individualized form. However, for all cases, the management of T2DM requires well-monitored glycemic control in order to control the progressive deterioration of $\beta$-cell function.

Conventional drugs and insulin are effective in treating the disease but unable to repair the associated metabolic and glucoregulatory dysfunctions, so combination therapies (drugs and diet) are gaining interest [176]. In this regard, incretin-based therapy and peptide analogs should be highlighted, since this method would allow to restore and preserve $\beta$-cell function and stop the progression of T2DM [177]. Furthermore, the increasing knowledge of the metabolism of this disease has demonstrated the benefits of phenolic compounds [178]. However, it is important to explore the common background of DM-mediated changes in pharmacokinetic and bioactivities of these dietary compounds, elucidate related mechanisms, and develop novel methods to improve the benefits of phenolic compounds and clinical outcomes for T2DM [179]. Phenolic compounds may be provided through the diet in foods such as tea or coffee, although its bioavailability is small [180]. Due to their low bioavailability, it is important to develop products with greater bioavailability. In this regard, the study of new plants and algae is remarkable as they are matrices rich in phenolic compounds. Moreover, several technologies should be developed to improve the bioavailability of dietary polyphenols, including nanotechnology and homogenization, as bioavailability depends on bioaccessibility, molecular structures, transporters, metabolizing enzymes, and food matrix effect [179]. Furthermore, the advancement in sophisticated omics methodologies has allowed the determination of molecules involved in nutritional genomics, metagenomics and other environmental exposures (mainly as markers of compliance). Consequently, the incorporation of techniques such as gene sequencing and omics will lead towards a molecular understanding of complex organisms [181].

However, to carry out all these advances in the market, it is necessary to take into account the current legislation. As it has been observed, many plant matrices have been used in traditional remedies to treat this disease, so they would not be subject to the new food legislation. However, the continuous progress of science, the discovery of new species and the study of others not used to date mean that many of them are considered as new food, which makes the process of commercialization much slower [182].

\section{CONCLUSION}

The treatment of patients with DM is considered a medical challenge due to the continuous increase in patients. This disease also depends on numerous factors that make its prevention more complex. In recent years, new therapeutic strategies have been developed based on traditional knowledge and the use of traditional plants and new sources with high anti-diabetic potential, such as algae. In fact, numerous scientific studies have demonstrated the beneficial properties of algal extracts and compounds (such as polysaccharides, phenolic compounds or pigments), both in vitro and in vivo studies. However, more clinical trials are still needed to determine its potential to develop new foods or anti-diabetic products. In addition, algae are highly accepted by consumers for being well valued as natural products. Dissemination of knowledge of diabetes as well as how to prevent or treat it to a wider audience is a potential method to control the diabetes epidemic. In the future, medical perspectives and new drug developments will be implemented to change the landscape of antidiabetic therapeutic study.

\section{LIST OF ABBREVIATIONS}

$$
\begin{aligned}
& \text { Generic } \\
& \mathrm{DM} \quad=\text { Diabetes mellitus } \\
& \text { GDM = Gestational diabetes mellitus } \\
& \text { HOMA-IR = Homeostatic Model Assess- } \\
& \text { IR } \quad=\text { Insulin resistance } \\
& \text { N.A = Not analyzed } \\
& \text { T1DM = Type } 1 \text { diabetes mellitus } \\
& \text { T2DM = Type } 2 \text { diabetes mellitus } \\
& \text { WHO = World health organization }
\end{aligned}
$$




$\begin{array}{ll}\text { GLUT4 } & =\text { Glucose transporter type } 4 \\ \text { HbAlc } & =\text { Glycated hemoglobin } \\ \text { HRAR } & =\text { Human recombinant aldose re- } \\ & =\text { Inctase } \\ \text { IRS } & =\text { phosphatidy receptor substrate } \\ \text { PI3K/Akt } & \text { nase/protein kinase B 3-ki- } \\ \text { PTP1B } & \text { Protein tyrosine phosphatase } \\ & =\text { Rat lens aldose reductase } \\ \text { RLAR } & =\text { Uncoupling protein one } \\ \text { UCP-1 } & =\text { Acetone } \\ \text { Solvents } & =\text { Commercial extract } \\ \text { AcO } & =\text { Ethyl Acetate } \\ \text { C.E } & =\text { Ethanol } \\ \text { EA } & =\text { Methanol } \\ \text { EtOH } & =\text { Water } \\ \text { MeOH } & \text { W }\end{array}$

\section{CONSENT FOR PUBLICATION}

Not applicable.

\section{FUNDING}

This study has been funded by the Ministry of Education, Science, and Technological Development of the Republic of Serbia (Grants Nos . 451-03-9/2021-14/200026, 451-03-9/2021-14/200378 and 451-03-9/2021-14/200122. In Spain and Portugal, the research leading to these results received financial support from Programa de Cooperación Interreg V-A España-Portugal (POCTEP) 2014-2020 (projects Ref.:

0181 NANOEATERS 01 E and Ref: 0377 IBERPHEN̄OL_6_E); to MICINN supporting the Ramón\&Cajal grant for M.A. Prieto (RYC-2017-22891); to Xunta de Galicia and University of Vigo supporting the pre-doctoral grants for A.G. Pereira (ED481A-2019/0228) and P. García-Oliveira (ED481A-2019/295); to Ibero-American Program on Science and Technology (CYTED - AQUA-CIBUS, P317RT0003) for financial support. This project has received funding from the Bio-Based Industries Joint Un-dertaking (JU) under grant agreement No 888003 UP-4HEALTH Project (H2020-BBI-JTI-2019), the JU re-ceives support from the European Union's Horizon 2020 research and innovation program and the Bio Based Industries Consortium.

\section{CONFLICT OF INTEREST}

The authors declare no conflicts of interest, financial or otherwise.

\section{ACKNOWLEDGEMENTS}

Serbian co-authors thank the Ministry of Education, Science, and Technological Development of the Republic of Serbia for the support within the contracts for the realization and financing of scientific research work in 2021 ; financial support from Programa de Cooperación Interreg V-A España-Portugal (POCTEP) 2014-2020; MICINN supporting the Ramón\&Cajal grant for M.A. Prieto; to Xunta de Galicia and University of Vigo supporting the pre-doctoral grants for A.G. Pereira, and P. García-Oliveira; to Ibero-American Program on Science and Technology for financial support. This project has received funding from the Bio Based Industries Joint Undertaking (JU); the JU receives support from the European Union's Horizon 2020 research and innovation program and the Bio Based Industries Consortium.

\section{REFERENCES}

[1] McGurk, S. Ganong's Review of Medical Physiology, $23^{\text {rd }}$ ed.; McGraw-Hill Professional Publishing: New York, USA, 2010, pp. 30-31.

[2] Bindu, J.; Narendhirakannan, R. Role of medicinal plants in the management of diabetes mellitus: a review. 3 Biotech, 2019, 9(1), 4.

http://dx.doi.org/10.1007/s13205-018-1528-0 PMID: 30555770

[3] Salehi, B.; Ata, A.; Kumar, N.V.A.; Sharopov, F.; Ramírez-Alarcón, K.; Ruiz-Ortega, A.; Ayatollahi, S.A.; Fokou, P.V.T.; Kobarfard, F.; Zakaria, Z.A.; Iriti, M.; Taheri, Y.; Martorell, M.; Sureda, A.; Setzer, W.N.; Durazzo, A.; Lucarini, M.; Santini, A.; Capasso, R.; Ostrander, E.A.; Rahman, A.; Choudhary, M.I.; Cho, W.C.; Sharifi-Rad, J. Antidiabetic potential of medicinal plants and their active components. Biomolecules, 2019, 9(10), 551.

http://dx.doi.org/10.3390/biom9100551 PMID: 31575072

[4] Unuofin, J.O.; Lebelo, S.L. Antioxidant effects and mechanisms of medicinal plants and their bioactive compounds for the prevention and treatment of type 2 diabetes: an updated review. Oxid. Med. Cell. Longev., 2020, 2020, 1356893.

http://dx.doi.org/10.1155/2020/1356893 PMID: 32148647

[5] Nazarian-Samani, Z.; Sewell, R.D.E.; Lorigooini, Z.; Rafieian-Kopaei, M. Medicinal plants with multiple effects on diabetes mellitus and its complications: a systematic review. Curr. Diab. Rep., 2018, 18(10), 72.

http://dx.doi.org/10.1007/s11892-018-1042-0 PMID: 30105479

[6] Ríos, J.L.; Francini, F.; Schinella, G.R. Natural products for the treatment of type 2 diabetes mellitus. Planta Med., 2015, 81(12-13), 975-994.

http://dx.doi.org/10.1055/s-0035-1546131 PMID: 26132858

[7] De Paoli, M.; Werstuck, G.H. Role of estrogen in type 1 and type 2 diabetes mellitus: a review of clinical and pre- 
clinical data. Can. J. Diabetes, 2020, 44(5), 448-452. http://dx.doi.org/10.1016/j.jcjd.2020.01.003 PMID: 32127295

[8] Teoh, S.L.; Das, S. Phytochemicals and their effective role in the treatment of diabetes mellitus: a short review. Phytochem. Rev., 2018, 17, 1111-1128. http://dx.doi.org/10.1007/s11101-018-9575-z

[9] CDC. Gestational Diabetes and Pregnancy Available online: https://www.cdc.gov/pregnancy/diabetes-gestational.html (Accessed: Sep 1, 2020).

[10] American Diabetes Association. Gestational Diabetes Symptoms and Diet. Available at: https://www.diabetes.org/diabetes/gestational-diabetes (Accessed: Sep 28, 2020).

[11] Popovic-Dordevic, J.B.; Jevtic, I.I.; Stanojkovic, T.P. Antidiabetics: structural diversity of molecules with a common aim. Curr. Med. Chem., 2018, 25(18), 2140-2165. http://dx.doi.org/10.2174/0929867325666171205145309 PMID: 29210642

[12] Seetaloo, A.D.; Aumeeruddy, M.Z.; Kannan, R.R.R.; Mahomoodally, M.F. Potential of traditionally consumed medicinal herbs, spices, and food plants to inhibit key digestive enzymes geared towards diabetes mellitus management - a systematic review. S. Afr. J. Bot., 2019, 120, 3-24. http://dx.doi.org/10.1016/j.sajb.2018.05.015

[13] Bi, X.; Lim, J.; Henry, C.J. Spices in the management of diabetes mellitus. Food Chem., 2017, 217, 281-293. http://dx.doi.org/10.1016/j.foodchem.2016.08.111 PMID: 27664636

[14] Governa, P.; Baini, G.; Borgonetti, V.; Cettolin, G.; Giachetti, D.; Magnano, A.R.; Miraldi, E.; Biagi, M. Phytotherapy in the management of diabetes: a review. Molecules, 2018, 23(1), 23.

http://dx.doi.org/10.3390/molecules23010105 PMID: 29300317

[15] Chinsembu, K.C. Diabetes mellitus and nature's pharmacy of putative antidiabetic plants. J. Herb. Med., 2019, 15, 100230.

http://dx.doi.org/10.1016/j.hermed.2018.09.001

[16] Ampofo, A.G.; Boateng, E.B. Beyond 2020: modelling obesity and diabetes prevalence. Diabetes Res. Clin. Pract., 2020, 167, 108362.

http://dx.doi.org/10.1016/j.diabres.2020.108362 PMID: 32758618

[17] Saeedi, P.; Petersohn, I.; Salpea, P.; Malanda, B.; Karuranga, S.; Unwin, N.; Colagiuri, S.; Guariguata, L.; Motala, A.A.; Ogurtsova, K.; Shaw, J.E.; Bright, D.; Williams, R. IDF Diabetes Atlas Committee. Global and regional diabetes prevalence estimates for 2019 and projections for 2030 and 2045: results from the International Diabetes Federation Diabetes Atlas, $9^{\text {th }}$ edition. Diabetes Res. Clin. Pract., 2019, 157, 107843.

http://dx.doi.org/10.1016/j.diabres.2019.107843 PMID: 31518657

[18] IDF Diabetes Atlas 9th edition 2019. Available online: https://www.diabetesatlas.org/en/

[19] NCD Risk Factor Collaboration (NCD-RisC). Worldwide trends in diabetes since 1980: a pooled analysis of 751 population-based studies with 4.4 million participants. Lancet, 2016, 387(10027), 1513-1530.

http://dx.doi.org/10.1016/S0140-6736(16)00618-8 PMID: 27061677

[20] Pociot, F.; Lernmark, A. Genetic risk factors for type 1 diabetes. Lancet, 2016, 387(10035), 2331-2339.

http://dx.doi.org/10.1016/S0140-6736(16)30582-7 PMID:
27302272

[21] World Health Organization. HEARTS D: Diagnosis and management of type 2 diabetes, 2020.

[22] Rasouli, H.; Yarani, R.; Pociot, F.; Popović-Djordjević, J Anti-diabetic potential of plant alkaloids: revisiting current findings and future perspectives. Pharmacol. Res., 2020, 155,104723 .

http://dx.doi.org/10.1016/j.phrs.2020.104723 PMID: 32105756

[23] Sami, W.; Ansari, T.; Butt, N.S.; Rashid, M.; Hamid, A. Effect of diet counseling on type 2 diabetes mellitus. Int. J. Sci. Technol. Res, 2015, 4(8), 112-118.

[24] Franz, M.J.; Bantle, J.P.; Beebe, C.A.; Brunzell, J.D.; Chiasson, J.L.; Garg, A.; Holzmeister, L.A.; Hoogwerf, B.; Mayer-Davis, E.; Mooradian, A.D.; Purnell, J.Q.; Wheeler, M. American Diabetes Association. Nutrition principles and recommendations in diabetes. Diabetes Care, 2004, 27(Suppl. 1), S36-S46.

http://dx.doi.org/10.2337/diacare.27.2007.s36 PMID: 14693924

[25] Schafer, R.G.; Bohannon, B.; Franz, M.J.; Freeman, J.; Holmes, A.; McLaughlin, S.; Haas, L.B.; Kruger, D.F.; Lorenz, R.A.; McMahon, M.M. American Diabetes Association. Diabetes nutrition recommendations for health care institutions. Diabetes Care, 2004, 27(Suppl. 1), S55-S57. http://dx.doi.org/10.2337/diacare.27.2007.s55 PMID: 14693926

[26] American Diabetes Association. Physical activity/exercise and diabetes. Diabetes Care, 2004, 27(Suppl. 1), S58-S62. http://dx.doi.org/10.2337/diacare.27.2007.s58 PMID: 14693927

[27] WHO Global report on diabetes, 2016. Available at: https://www.who.int/publications/i/item/9789241565257 (Accessed: Sep 1, 2020).

[28] Marchini, F.; Caputo, A.; Napoli, A.; Balonan, J.T.; Martino, G.; Nannini, V.V.L. Chronic illness as loss of good self: underlying mechanisms affecting diabetes adaptation. Mediterr. J. Clin. Psychol., 2018, 6, 1-25.

http://dx.doi.org/10.6092/2282-1619/2018.6.1981

[29] Herman, W.H. The Global burden of diabetes: an overview. In: Diabetes Mellitus in Developing Countries and Underserved Communities; Springer International Publishing Switzerland, 2017; pp. 1-5.

http://dx.doi.org/10.1007/978-3-319-41559-8_1

[30] Herman, W.H. The global agenda for the prevention of type 2 diabetes. Nutr. Rev., 2017, 75(Suppl. 1), 13-18. http://dx.doi.org/10.1093/nutrit/nuw034 PMID: 28049746

[31] Li, J.; Bai, L.; Wei, F.; Zhao, J.; Wang, D.; Xiao, Y.; Yan, W.; Wei, J. Therapeutic mechanisms of herbal medicines against insulin resistance: a review. Front. Pharmacol., 2019, 10, 661 .

http://dx.doi.org/10.3389/fphar.2019.00661 PMID: 31258478

[32] Zheng, Y.; Ley, S.H.; Hu, F.B. Global aetiology and epidemiology of type 2 diabetes mellitus and its complications. Nat. Rev. Endocrinol., 2018, 14(2), 88-98. http://dx.doi.org/10.1038/nrendo.2017.151 29219149

[33] McMacken, M.; Shah, S. A plant-based diet for the prevention and treatment of type 2 diabetes. J. Geriatr. Cardiol., 2017, 14(5), 342-354.

http://dx.doi.org/10.11909/j.issn.1671-5411.2017.05.009 PMID: 28630614

[34] Dinu, M.; Abbate, R.; Gensini, G.F.; Casini, A.; Sofi, F. Vegetarian, vegan diets and multiple health outcomes: a 
systematic review with meta-analysis of observational studies. Crit. Rev. Food Sci. Nutr., 2017, 57(17), 3640-3649.

http://dx.doi.org/10.1080/10408398.2016.1138447 PMID: 26853923

[35] Torsoni, A.S.; Milanski, M.; Torsoni, M.A. Dietary Patterns and Insulin Resistance. In: Molecular Nutrition and Diabetes: A Volume in the Molecular Nutrition Series; Elsevier Inc., 2016; pp. 19-28.

http://dx.doi.org/10.1016/B978-0-12-801585-8.00002-6

[36] von Frankenberg, A.D.; Marina, A.; Song, X.; Callahan, H.S.; Kratz, M.; Utzschneider, K.M. A high-fat, high-saturated fat diet decreases insulin sensitivity without changing intra-abdominal fat in weight-stable overweight and obese adults. Eur. J. Nutr., 2017, 56(1), 431-443.

http://dx.doi.org/10.1007/s00394-015-1108-6 PMID: 26615402

[37] Luukkonen, P.K.; Sädevirta, S.; Zhou, Y.; Kayser, B.; Ali, A.; Ahonen, L.; Lallukka, S.; Pelloux, V.; Gaggini, M.; Jian, C. Saturated fat is more metabolically harmful for the human liver than unsaturated fat or simple sugars. Proceedings of the Diabetes Care, 2018, Vol. 41, 1732-1739. http://dx.doi.org/10.2337/dc18-0071

[38] Weickert, M.O.; Pfeiffer, A.F.H. Impact of dietary fiber consumption on insulin resistance and the prevention of type 2 diabetes. $J$. Nutr., 2018, 148(1), 7-12.

http://dx.doi.org/10.1093/jn/nxx008 PMID: 29378044

[39] Hernández, M.A.G.; Canfora, E.E.; Jocken, J.W.E.; Blaak, E.E. The short-chain fatty acid acetate in body weight control and insulin sensitivity. Nutrients, 2019, 11(8), 11. http://dx.doi.org/10.3390/nu11081943 PMID: 31426593

[40] Weickert, M.O. Nutritional modulation of insulin resistance. Scientifica (Cairo), 2012, 2012, 424780. http://dx.doi.org/10.6064/2012/424780 PMID: 24278690

[41] Sears, B.; Perry, M. The role of fatty acids in insulin resistance. Lipids Health Dis., 2015, 14(1), 121.

http://dx.doi.org/10.1186/s12944-015-0123-1 PMID: 26415887

[42] Hardy, O.T.; Czech, M.P.; Corvera, S. What causes the insulin resistance underlying obesity? Curr. Opin. Endocrinol. Diabetes Obes., 2012, 19(2), 81-87.

http://dx.doi.org/10.1097/MED.0b013e3283514e13 PMID: 22327367

[43] Assali, A.R.; Ganor, A.; Beigel, Y.; Shafer, Z.; Hershcovici, T.; Fainaru, M. Insulin resistance in obesity: bodyweight or energy balance? J. Endocrinol., 2001, 171(2), 293-298.

http://dx.doi.org/10.1677/joe.0.1710293 PMID: 11691649

[44] Caricilli, A.M.; Saad, M.J.A. The role of gut microbiota on insulin resistance. Nutrients, 2013, 5(3), 829-851. http://dx.doi.org/10.3390/nu5030829 PMID: 23482058

[45] Gurung, M.; Li, Z.; You, H.; Rodrigues, R.; Jump, D.B.; Morgun, A.; Shulzhenko, N. Role of gut microbiota in type 2 diabetes pathophysiology. EBioMedicine, 2020, 51, 102590.

http://dx.doi.org/10.1016/j.ebiom.2019.11.051 PMID: 31901868

[46] Aydin, Ö.; Nieuwdorp, M.; Gerdes, V. The gut microbiome as a target for the treatment of type 2 diabetes. Curr. Diab. Rep., 2018, 18(8), 55.

http://dx.doi.org/10.1007/s11892-018-1020-6 PMID: 29931613

[47] Tong, M.; Neusner, A.; Longato, L.; Lawton, M.; Wands, J.R.; de la Monte, S.M. Nitrosamine exposure causes insulin resistance diseases: relevance to type 2 diabetes melli- tus, non-alcoholic steatohepatitis, and Alzheimer's disease. J. Alzheimers Dis., 2009, 17(4), 827-844.

PMID: 20387270

[48] Kim, Y.; Keogh, J.; Clifton, P. A review of potential metabolic etiologies of the observed association between red meat consumption and development of type 2 diabetes mellitus. Metabolism, 2015, 64(7), 768-779.

http://dx.doi.org/10.1016/j.metabol.2015.03.008 PMID: 25838035

[49] Simcox, J.A.; McClain, D.A. Iron and diabetes risk. Cell Metab., 2013, 17(3), 329-341.

http://dx.doi.org/10.1016/j.cmet.2013.02.007 PMID: 23473030

[50] White, D.L.; Collinson, A. Red meat, dietary heme iron, and risk of type 2 diabetes: the involvement of advanced lipoxidation endproducts. Adv. Nutr., 2013, 4(4), 403-411. http://dx.doi.org/10.3945/an.113.003681 PMID: 23858089

[51] Krisai, P.; Leib, S.; Aeschbacher, S.; Kofler, T.; Assadian, M.; Maseli, A.; Todd, J.; Estis, J.; Risch, M.; Risch, L.; Conen, D. Relationships of iron metabolism with insulin resistance and glucose levels in young and healthy adults. Eur. J. Intern. Med., 2016, 32, 31-37.

http://dx.doi.org/10.1016/j.ejim.2016.03.017 PMID: 27113814

[52] Fargion, S.; Dongiovanni, P.; Guzzo, A.; Colombo, S.; Valenti, L.; Fracanzani, A.L. Iron and insulin resistance. Aliment. Pharmacol. Ther., 2005, 22(Suppl. 2), 61-63. http://dx.doi.org/10.1111/j.1365-2036.2005.02599.x PMID: 16225476

[53] Unoki, H.; Yamagishi, S. Advanced glycation end products and insulin resistance. Curr. Pharm. Des., 2008, 14(10), 987-989.

http://dx.doi.org/10.2174/138161208784139747 PMID: 18473850

[54] Cai, W.; Ramdas, M.; Zhu, L.; Chen, X.; Striker, G.E.; Vlassara, H. Oral advanced glycation endproducts (AGEs) promote insulin resistance and diabetes by depleting the antioxidant defenses AGE receptor-1 and sirtuin 1. Proc. Natl. Acad. Sci. USA, 2012, 109(39), 15888-15893. http://dx.doi.org/10.1073/pnas.1205847109 PMID: 22908267

[55] Song, F.; Schmidt, A.M. Glycation and insulin resistance: novel mechanisms and unique targets? Arterioscler. Thromb. Vasc. Biol., 2012, 32(8), 1760-1765. http://dx.doi.org/10.1161/ATVBAHA.111.241877 PMID: 22815341

[56] Pinto-Junior, D.C.; Silva, K.S.; Michalani, M.L.; Yonamine, C.Y.; Esteves, J.V.; Fabre, N.T.; Thieme, K.; Catanozi, S.; Okamoto, M.M.; Seraphim, P.M.; Corrêa-Giannella, M.L.; Passarelli, M.; Machado, U.F. Advanced glycation end products-induced insulin resistance involves repression of skeletal muscle GLUT4 expression. Sci. Rep., 2018, $8(1), 8109$.

http://dx.doi.org/10.1038/s41598-018-26482-6 PMID: 29802324

[57] de Courten, B.; de Courten, M.P.; Soldatos, G.; Dougherty, S.L.; Straznicky, N.; Schlaich, M.; Sourris, K.C.; Chand, V.; Scheijen, J.L.; Kingwell, B.A.; Cooper, M.E.; Schalkwijk, C.G.; Walker, K.Z.; Forbes, J.M. Diet low in advanced glycation end products increases insulin sensitivity in healthy overweight individuals: a double-blind, randomized, crossover trial. Am. J. Clin. Nutr., 2016, 103(6), 1426-1433.

http://dx.doi.org/10.3945/ajen.115.125427 PMID: 27030534 
[58] Uribarri, J.; Cai, W.; Ramdas, M.; Goodman, S.; Pyzik, R.; Chen, X.; Zhu, L.; Striker, G.E.; Vlassara, H. Restriction of advanced glycation end products improves insulin resistance in human type 2 diabetes: potential role of AGER1 and SIRT1. Diabetes Care, 2011, 34(7), 1610-1616. http://dx.doi.org/10.2337/dc11-0091 PMID: 21709297

[59] Sanlier, N.; Gencer, F. Role of spices in the treatment of diabetes mellitus: a minireview. Trends Food Sci. Technol., 2020, 99, 441-449.

http://dx.doi.org/10.1016/j.tifs.2020.03.018

[60] Khursheed, R.; Singh, S.K.; Wadhwa, S.; Gulati, M.; Awasthi, A. Therapeutic potential of mushrooms in diabetes mellitus: role of polysaccharides. Int. J. Biol. Macromol., 2020, 164, 1194-1205.

http://dx.doi.org/10.1016/j.ijbiomac.2020.07.145 PMID: 32693144

[61] Choudhury, H.; Pandey, M.; Hua, C.K.; Mun, C.S.; Jing, J.K.; Kong, L.; Ern, L.Y.; Ashraf, N.A.; Kit, S.W.; Yee, T.S.; Pichika, M.R.; Gorain, B.; Kesharwani, P. An update on natural compounds in the remedy of diabetes mellitus: a systematic review. J. Tradit. Complement. Med., 2017, $8(3), 361-376$.

http://dx.doi.org/10.1016/j.jtcme.2017.08.012 PMID: 29992107

[62] Hajizadeh-Sharafabad, F.; Varshosaz, P.; Jafari-Vayghan, H.; Alizadeh, M.; Maleki, V. Chamomile (Matricaria recutita L.) and diabetes mellitus, current knowledge and the way forward: a systematic review. Complement. Ther. Med., 2020, 48, 102284.

http://dx.doi.org/10.1016/j.ctim.2019.102284 PMID: 31987240

[63] Deyno, S.; Eneyew, K.; Seyfe, S.; Tuyiringire, N.; Peter, E.L.; Muluye, R.A.; Tolo, C.U.; Ogwang, P.E. Efficacy and safety of cinnamon in type 2 diabetes mellitus and pre-diabetes patients: a meta-analysis and meta-regression. Diabetes Res. Clin. Pract., 2019, 156, 107815.

http://dx.doi.org/10.1016/j.diabres.2019.107815 PMID: 31425768

[64] Zengin, G.; Ceylan, R.; Katanić, J.; Aktumsek, A.; Matić, S.; Boroja, T.; Stanić, S.; Mihailović, V.; Seebaluck-Sandoram, R.; Mollica, A. Exploring the therapeutic potential and phenolic composition of two Turkish ethnomedicinal plants - Ajuga orientalis L. and Arnebia densiflora (Nordm.) Ledeb. Ind. Crops Prod., 2018, 116, 240-248. http://dx.doi.org/10.1016/j.indcrop.2018.02.054

[65] Ballali, S.; Lanciai, F. Functional food and diabetes: a natural way in diabetes prevention? Int. J. Food Sci. Nutr., 2012, 63(Suppl. 1), 51-61.

http://dx.doi.org/10.3109/09637486.2011.637487 PMID: 22107597

[66] El-Abhar, H.S.; Schaalan, M.F. Phytotherapy in diabetes: review on potential mechanistic perspectives. World J. Diabetes, 2014, 5(2), 176-197.

http://dx.doi.org/10.4239/wjd.v5.i2.176 PMID: 24748931

[67] Sengupta, K.; Mishra, A.T.; Rao, M.K.; Sarma, K.V.S.; Krishnaraju, A.V.; Trimurtulu, G. Efficacy and tolerability of a novel herbal formulation for weight management in obese subjects: a randomized double blind placebo controlled clinical study. Lipids Health Dis., 2012, 11, 122. http://dx.doi.org/10.1186/1476-511X-11-122 PMID: 22995673

[68] Basch, E.; Ulbricht, C.; Kuo, G.; Szapary, P.; Smith, M. Therapeutic applications of fenugreek. Altern. Med. Rev., 2003, 8(1), 20-27.

PMID: 12611558
[69] Dar, S.A.; Ganai, F.A.; Yousuf, A.R.; Balkhi, M.U.H.; Bhat, T.M.; Sharma, P. Pharmacological and toxicological evaluation of Urtica dioica. Pharm. Biol., 2013, 51(2), 170-180.

http://dx.doi.org/10.3109/13880209.2012.715172 PMID: 23036051

[70] Rau, O.; Wurglics, M.; Dingermann, T.; Abdel-Tawab, M.; Schubert-Zsilavecz, M. Screening of herbal extracts for activation of the human peroxisome proliferator-activated receptor. Pharmazie, 2006, 61(11), 952-956. PMID: 17152989

[71] Rahimzadeh, M.; Jahanshahi, S.; Moein, S.; Moein, M.R. Evaluation of alpha-amylase inhibition by Urtica dioica and Juglans regia extracts. Iran. J. Basic Med. Sci., 2014, 17(6), 465-469.

PMID: 25140210

[72] Nagao, T.; Meguro, S.; Hase, T.; Otsuka, K.; Komikado, M.; Tokimitsu, I.; Yamamoto, T.; Yamamoto, K. A catechin-rich beverage improves obesity and blood glucose control in patients with type 2 diabetes. Obesity (Silver Spring), 2009, 17(2), 310-317.

http://dx.doi.org/10.1038/oby.2008.505 PMID: 19008868

[73] Hayward, N.J.; McDougall, G.J.; Farag, S.; Allwood, J.W.; Austin, C.; Campbell, F.; Horgan, G.; Ranawana, V. Cinnamon shows antidiabetic properties that are species-specific: effects on enzyme activity inhibition and starch digestion. Plant Foods Hum. Nutr., 2019, 74(4), 544-552. http://dx.doi.org/10.1007/s11130-019-00760-8 PMID: 31372918

[74] Anderson, R.A.; Zhan, Z.; Luo, R.; Guo, X.; Guo, Q.; Zhou, J.; Kong, J.; Davis, P.A.; Stoecker, B.J. Cinnamon extract lowers glucose, insulin and cholesterol in people with elevated serum glucose. J. Tradit. Complement. Med., 2015, 6(4), 332-336.

http://dx.doi.org/10.1016/j.jtcme.2015.03.005 PMID: 27774415

[75] Salim, B.; Said, G.; Kambouche, N.; Kress, S. Identification of phenolic compounds from nettle as new candidate inhibitors of main enzymes responsible on type-II diabetes. Curr. Drug Discov. Technol., 2020, 17(2), 197-202. http://dx.doi.org/10.2174/1570163815666180829094831 PMID: 30156162

[76] Xing, L.; Zhang, H.; Qi, R.; Tsao, R.; Mine, Y. Recent advances in the understanding of the health benefits and molecular mechanisms associated with green tea polyphenols. J. Agric. Food Chem., 2019, 67(4), 1029-1043. http://dx.doi.org/10.1021/acs.jafc.8b06146 PMID: 30653316

[77] Tang, G.Y.; Meng, X.; Gan, R.Y.; Zhao, C.N.; Liu, Q.; Feng, Y.B.; Li, S.; Wei, X.L.; Atanasov, A.G.; Corke, H.; Li, H.B. Health functions and related molecular mechanisms of tea components: an update review. Int. J. Mol. Sci., 2019, 20(24), 20.

http://dx.doi.org/10.3390/ijms20246196 PMID: 31817990

[78] Blevins, S.M.; Leyva, M.J.; Brown, J.; Wright, J.; Scofield, R.H.; Aston, C.E. Effect of cinnamon on glucose and lipid levels in non insulin-dependent type 2 diabetes. Diabetes Care, 2007, 30(9), 2236-2237.

http://dx.doi.org/10.2337/dc07-0098 PMID: 17563345

[79] Jiang, S.; Xu, L.; Xu, Y.; Guo, Y.; Wei, L.; Li, X.; Song, W. Antidiabetic effect of Momordica charantia saponins in rats induced by high-fat diet combined with STZ. Electron. J. Biotechnol., 2020, 43, 41-47.

http://dx.doi.org/10.1016/j.ejbt.2019.12.001

[80] Kim, S.K.; Jung, J.; Jung, J.H.; Yoon, N.; Kang, S.S.; Roh, 
G.S.; Hahm, J.R. Hypoglycemic efficacy and safety of $\mathrm{Mo}$ mordica charantia (bitter melon) in patients with type 2 diabetes mellitus. Complement. Ther. Med., 2020, 52, 102524.

http://dx.doi.org/10.1016/j.ctim.2020.102524 PMID: 32951763

[81] Dwijayanti, D.R.; Shimada, T.; Ishii, T.; Okuyama, T.; Ikeya, Y.; Mukai, E.; Nishizawa, M. Bitter melon fruit extract has a hypoglycemic effect and reduces hepatic lipid accumulation in ob/ob mice. Phytother. Res., 2020, 34(6), 1338-1346.

http://dx.doi.org/10.1002/ptr.6600 PMID: 31845444

[82] Shivanagoudra, S.R.; Perera, W.H.; Perez, J.L.; Athrey, G.; Sun, Y.; Wu, C.S.; Jayaprakasha, G.K.; Patil, B.S. In vitro and in silico elucidation of antidiabetic and anti-inflammatory activities of bioactive compounds from $\mathrm{Mo}$ mordica charantia L. Bioorg. Med. Chem., 2019, 27(14), 3097-3109.

http://dx.doi.org/10.1016/j.bmc.2019.05.035 PMID: 31196754

[83] Li, G.; Luan, G.; He, Y.; Tie, F.; Wang, Z.; Suo, Y.; Ma, C.; Wang, H. Polyphenol stilbenes from fenugreek (Trigonella foenumgraecum $L$.) seeds improve insulin sensitivity and mitochondrial function in 3T3-L1 adipocytes. Oxid. Med. Cell. Longev., 2018, 2018, 7634362.

http://dx.doi.org/10.1155/2018/7634362 PMID: 29967664

[84] Geberemeskel, G.A.; Debebe, Y.G.; Nguse, N.A. Antidiabetic effect of fenugreek seed powder solution (Trigonella foenum-graecum L.) on hyperlipidemia in diabetic patients. J. Diabetes Res., 2019, 2019, 8507453.

http://dx.doi.org/10.1155/2019/8507453 PMID: 31583253

[85] Nurmaylindha, V.; Widodo, G.P.; Herowati, R. Molecular docking analysis of Leucaena leucocephala and Trigonella foenum-graecum chemical constituents on antidiabetic macromolecular targets and prediction of the pharmacokinetic profiles. In: AIP Conference Proceedings; , 2020; Vol. 2243, p. 020015.

http://dx.doi.org/10.1063/5.0006279

[86] Pereira, A.G.; Jimenez-Lopez, C.; Fraga, M.; LourençoLopes, C.; García-Oliveira, P.; Lorenzo, J.M.; PerezLamela, C.; Prieto, M.A.; Simal-Gandara, J. Extraction, properties, and applications of bioactive compounds obtained from microalgae. Curr. Pharm. Des., 2020, 26(16), 1929-1950.

http://dx.doi.org/10.2174/1381612826666200403172206 PMID: 32242779

[87] Zakaria, S.M.; Kamal, S.M.M. Subcritical water extraction of bioactive compounds from plants and algae: applications in pharmaceutical and food ingredients. Food Eng. Rev., 2016, 8, 23-34.

http://dx.doi.org/10.1007/s12393-015-9119-x

[88] Shirosaki, M.; Koyama, T. Antidiabetic Compounds from Marine Organisms and Their Properties. In: Marine Pharmacognosy: Trends and Applications; Se-Kwon, Kim CRC Press: Boca Raton, 2012; pp. 7-19.

[89] Torsdottir, I.; Alpsten, M.; Holm, G.; Sandberg, A.S.; Tö1li, J. A small dose of soluble alginate-fiber affects postprandial glycemia and gastric emptying in humans with diabetes. J. Nutr., 1991, 121(6), 795-799. http://dx.doi.org/10.1093/jn/121.6.795 PMID: 1851824

[90] Sakai, C.; Abe, S.; Kouzuki, M.; Shimohiro, H.; Ota, Y.; Sakinada, H.; Takeuchi, T.; Okura, T.; Kasagi, T.; Hanaki, $\mathrm{K}$. A randomized placebo-controlled trial of an oral preparation of high molecular weight fucoidan in patients with type 2 diabetes with evaluation of taste sensitivity. Yonago
Acta Med., 2019, 62(1), 14-23.

http://dx.doi.org/10.33160/yam.2019.03.003 PMID: 30962740

[91] Lee, S.H.; Jeon, Y.J. Anti-diabetic effects of brown algae derived phlorotannins, marine polyphenols through diverse mechanisms. Fitoterapia, 2013, 86, 129-136.

http://dx.doi.org/10.1016/j.fitote.2013.02.013 PMID: 23466874

[92] Kawee-Ai, A.; Kim, A.T.; Kim, S.M. Inhibitory activities of microalgal fucoxanthin against $\alpha$-amylase, $\alpha$-glucosidase, and glucose oxidase in 3T3-L1 cells linked to type 2 diabetes. J. Oceanol. Limnol., 2019, 37, 928-937.

http://dx.doi.org/10.1007/s00343-019-8098-9

[93] Gunathilaka, T.L.; Samarakoon, K.; Ranasinghe, P.; Peiris, L.D.C. Antidiabetic potential of marine brown algae-a mini review. J. Diabetes Res., 2020, 2020, 1230218. http://dx.doi.org/10.1155/2020/1230218 PMID: 32377517

[94] Lee, S.H. Yong-Li; Karadeniz, F.; Kim, M.M.; Kim, S.K. $\alpha$-Glucosidase and $\alpha$-amylase inhibitory activities of phloroglucinal derivatives from edible marine brown alga, Ecklonia cava. J. Sci. Food Agric., 2009, 89, 1552-1558. http://dx.doi.org/10.1002/jsfa.3623

[95] Lee, H.A.; Song, Y.O.; Jang, M.S.; Han, J.S. Alleviating effects of baechu kimchi added Ecklonia cava on postprandial hyperglycemia in diabetic mice. Prev. Nutr. Food Sci., 2013, 18(3), 163-168.

http://dx.doi.org/10.3746/pnf.2013.18.3.163 PMID: 24471127

[96] Lee, H.A.; Song, Y.O.; Jang, M.S.; Han, J.S. Effect of Baechu kimchi added Ecklonia cava extracts on high glucose-induced oxidative stress in human umbilical vein endothelial cells. Prev. Nutr. Food Sci., 2014, 19(3), 170-177.

http://dx.doi.org/10.3746/pnf.2014.19.3.170 PMID: 25320714

[97] Yoon, J.Y.; Choi, H.; Jun, H.S. The effect of phloroglucinol, a component of Ecklonia cava extract, on hepatic glucose production. Mar. Drugs, 2017, 15(4), 15.

http://dx.doi.org/10.3390/md15040106 PMID: 28379184

[98] Lee, S.H.; Min, K.H.; Han, J.S.; Lee, D.H.; Park, D.B.; Jung, W.K.; Park, P.J.; Jeon, B.T.; Kim, S.K.; Jeon, Y.J. Effects of brown alga, Ecklonia cava on glucose and lipid metabolism in C57BL/KsJ-db/db mice, a model of type 2 diabetes mellitus. Food Chem. Toxicol., 2012, 50(3-4), 575-582.

http://dx.doi.org/10.1016/j.fct.2011.12.032 PMID: 22227338

[99] Kim, M.J.; Kim, H.K. Insulinotrophic and hypolipidemic effects of Ecklonia cava in streptozotocin-induced diabetic mice. Asian Pac. J. Trop. Med., 2012, 5(5), 374-379. http://dx.doi.org/10.1016/S1995-7645(12)60062-5 PMID: 22546654

[100] Daub, C.D.; Mabate, B.; Malgas, S.; Pletschke, B.I. Fucoidan from Ecklonia maxima is a powerful inhibitor of the diabetes-related enzyme, $\alpha$-glucosidase. Int. J. Biol. Macromol., 2020, 151, 412-420.

http://dx.doi.org/10.1016/j.ijbiomac.2020.02.161 PMID: 32070744

[101] Rengasamy, K.R.R.; Aderogba, M.A.; Amoo, S.O.; Stirk, W.A.; Van Staden, J. Potential antiradical and alpha-glucosidase inhibitors from Ecklonia maxima (Osbeck) Papenfuss. Food Chem., 2013, 141(2), 1412-1415. http://dx.doi.org/10.1016/j.foodchem.2013.04.019 PMID: 23790932

[102] Xu, H.L.; Kitajima, C.; Ito, H.; Miyazaki, T.; Baba, M.; 
Okuyama, T.; Okada, Y. Antidiabetic effect of polyphenols from brown alga Ecklonia kurome in genetically diabetic KK-A(y) mice. Pharm. Biol., 2012, 50(3), 393-400.

http://dx.doi.org/10.3109/13880209.2011.601464 PMID: 22103717

[103] Dwiranti, F.; Hiraoka, M.; Taguchi, T.; Konishi, Y.; Tominaga, M.; Tominaga, A. Effects of gametophytes of Ecklonia kurome on the levels of glucose and triacylglycerol in $\mathrm{db} / \mathrm{db}$, prediabetic $\mathrm{C} 57 \mathrm{BL} / 6 \mathrm{~J}$ and IFN- $\gamma$ KO Mice. Int. $J$. Biomed. Sci., 2012, 8(1), 64-75.

PMID: 23675258

[104] Jung, H.A.; Yoon, N.Y.; Woo, M.-H.; Choi, J.S. Inhibitory activities of extracts from several kinds of seaweeds and phlorotannins from the brown alga Ecklonia stolonifera on glucose-mediated protein damage and rat lens aldose reductase. Fish. Sci., 2008, 74, 1363-1365.

http://dx.doi.org/10.1111/j.1444-2906.2008.01670.x

[105] Iwai, K. Antidiabetic and antioxidant effects of polyphenols in brown alga Ecklonia stolonifera in genetically diabetic KK-A(y) mice. Plant Foods Hum. Nutr., 2008, 63(4), 163-169.

http://dx.doi.org/10.1007/s11130-008-0098-4 PMID: 18958624

[106] Moon, H.E.; Islam, N.; Ahn, B.R.; Chowdhury, S.S.; Sohn, H.S.; Jung, H.A.; Choi, J.S. Protein tyrosine phosphatase $1 \mathrm{~B}$ and $\alpha$-glucosidase inhibitory phlorotannins from edible brown algae, Ecklonia stolonifera and Eisenia bicyclis. Biosci. Biotechnol. Biochem., 2011, 75(8), 1472-1480. http://dx.doi.org/10.1271/bbb.110137 PMID: 21821954

[107] Shirosaki, M.; Koyama, T. Laminaria japonica as a food for the prevention of obesity and diabetes. Adv. Food Nutr. Res., 2011, 64, 199-212.

http://dx.doi.org/10.1016/B978-0-12-387669-0.00015-6 PMID: 22054948

[108] Vaugelade, P.; Hoebler, C.; Bernard, F.; Guillon, F.; Lahaye, M.; Duee, P.H.; Darcy-Vrillon, B. Non-starch polysaccharides extracted from seaweed can modulate intestinal absorption of glucose and insulin response in the pig. Reprod. Nutr. Dev., 2000, 40(1), 33-47. http://dx.doi.org/10.1051/rnd:2000118 PMID: 10737549

[109] Liu, M.; Zhang, W.; Qiu, L.; Lin, X. Synthesis of butyl-isobutyl-phthalate and its interaction with $\alpha$-glucosidase in vitro. J. Biochem., 2011, 149(1), 27-33. http://dx.doi.org/10.1093/jb/mvq110 PMID: 20870646

[110] Bu, T.; Liu, M.; Zheng, L.; Guo, Y.; Lin, X. $\alpha$-Glucosidase inhibition and the in vivo hypoglycemic effect of butyl-isobutyl-phthalate derived from the Laminaria japonica rhizoid. Phytother. Res., 2010, 24(11), 1588-1591. http://dx.doi.org/10.1002/ptr.3139 PMID: 21031613

[111] Fried, R.; Carlton, R.M. Type 2 diabetes: Cardiovascular and Related Complications and Evidence-Based Complementary Treatments, $1^{\text {st }}$ ed.; CRC Press, 2018, p. 510. http://dx.doi.org/10.1201/9780429507250

[112] Son, Y.K.; Jin, S.E.; Kim, H.R.; Woo, H.C.; Jung, H.A.; Choi, J.S. Inhibitory activities of the edible brown alga Laminaria japonica on glucose-mediated protein damage and rat lens aldose reductase. Fish. Sci., 2011, 77(6), 1069-1079.

http://dx.doi.org/10.1007/s12562-011-0406-Z

[113] Kang, S.-Y.; Kim, E.; Kang, I.; Lee, M.; Lee, Y. Anti-diabetic effects and anti-inflammatory effects of Laminaria japonica and Hizikia fusiforme in skeletal muscle: In vitro and in vivo model. Nutrients, 2018, 10, 491. http://dx.doi.org/10.3390/nu10040491
[114] Li, X.; Yu, Z.; Long, S.; Guo, Y.; Duan, D. Hypoglycemic effect of Laminaria japonica polysaccharide in a type 2 diabetes mellitus mouse model. ISRN Endocrinol., 2012, $2012,507462$.

http://dx.doi.org/10.5402/2012/507462 PMID: 23209930

[115] Jia, X.; Yang, J.; Wang, Z.; Liu, R.; Xie, R. Polysaccharides from Laminaria japonica show hypoglycemic and hypolipidemic activities in mice with experimentally induced diabetes. Exp. Biol. Med. (Maywood), 2014, 239(12), 1663-1670.

http://dx.doi.org/10.1177/1535370214537751 PMID: 24928865

[116] Sørensen, L.E.; Jeppesen, P.B.; Christiansen, C.B.; Hermansen, K.; Gregersen, S. Nordic seaweed and diabetes prevention: Exploratory studies in KK-Ay mice. Nutrients, 2019, 11(6), 11. http://dx.doi.org/10.3390/nu11061435 PMID: 31242682

[117] Wang, J.; Jin, W.; Zhang, W.; Hou, Y.; Zhang, H.; Zhang, Q. Hypoglycemic property of acidic polysaccharide extracted from Saccharina japonica and its potential mechanism. Carbohydr. Polym., 2013, 95(1), 143-147.

http://dx.doi.org/10.1016/j.carbpol.2013.02.076 PMID: 23618250

[118] Kim, M.S.; Kim, J.Y.; Choi, W.H.; Lee, S.S. Effects of seaweed supplementation on blood glucose concentration, lipid profile, and antioxidant enzyme activities in patients with type 2 diabetes mellitus. Nutr. Res. Pract., 2008, 2(2), 62-67.

http://dx.doi.org/10.4162/nrp.2008.2.2.62 PMID: 20126367

[119] Suraiya, S.; Lee, J.M.; Cho, H.J.; Jang, W.J.; Kim, D.G.; Kim, Y.O.; Kong, I.S. Monascus spp. fermented brown seaweeds extracts enhance bio-functional activities. Food Biosci., 2018.

http://dx.doi.org/10.1016/j.fbio.2017.12.005

[120] Long, S.H.; Yu, Z.Q.; Shuai, L.; Guo, Y.L.; Duan, D.L.; $\mathrm{Xu}, \mathrm{X} . Y$.; Li, X.D. The hypoglycemic effect of the kelp on diabetes mellitus model induced by alloxan in rats. Int. J. Mol. Sci., 2012, 13(3), 3354-3365.

http://dx.doi.org/10.3390/ijms13033354 PMID: 22489155

[121] Han, Y.R.; Ali, M.Y.; Woo, M.-H.; Jung, H.A.; Choi, J.S. Anti-diabetic and anti-inflammatory potential of the edible brown alga Hizikia fusiformis. J. Food Biochem., 2015, 39, 417-428. http://dx.doi.org/10.1111/jfbc. 12138

[122] Tong, T.; Zhang, C.; Ko, D.-O.; Kim, S.-B.; Jung, K.-J.; Kan, S.-G. Effects of the addition of Hizikia fusiforme, Capsosiphon fulvescens, and Undaria pinnatifida sporophyll on antioxidant and inhibitory potential against enzymes related to type 2 diabetes of vegetable extract. Korean J. Food Preserv., 2014, 21, 460-467. http://dx.doi.org/10.11002/kjfp.2014.21.4.460

[123] Cheng, Y.; Sibusiso, L.; Hou, L.; Jiang, H.; Chen, P.; Zhang, X.; Wu, M.; Tong, H. Sargassum fusiforme fucoidan modifies the gut microbiota during alleviation of streptozotocin-induced hyperglycemia in mice. Int. J. Biol. Macromol., 2019, 131, 1162-1170.

http://dx.doi.org/10.1016/j.ijbiomac.2019.04.040 PMID: 30974142

[124] Mei-shu, S. Protective effects of Sargassum fusiforme polysaccharide on type 2 diabetes mellitus nephropathy rats and its mechanism. Chinese J. Mar. Drugs, 2010, 3, 38-41.

[125] Lee, C.W.; Han, J.S. Hypoglycemic effect of Sargassum ringgoldianum extract in STZ-induced diabetic mice. Prev. 
Nutr. Food Sci., 2012, 17(1), 8-13. http://dx.doi.org/10.3746/pnf.2012.17.1.008 PMID: 24471057

[126] Akbarzadeh, S.; Gholampour, H.; Farzadinia, P.; Daneshi, A.; Ramavandi, B.; Moazzeni, A.; Keshavarz, M.; Bargahi, A. Anti-diabetic effects of Sargassum oligocystum on streptozotocin-induced diabetic rat. Iran. J. Basic Med. Sci., 2018, 21(3), 342-346.

http://dx.doi.org/10.22038/ijbms.2018.25654.6329 PMID: 29511502

[127] Selvaraj, S.; Palanisamy, S. Investigations on the anti-diabetic potential of novel marine seaweed Sargassum longiotom against alloxan-induced diabetes mellitus: a pilot study. Bangladesh J. Pharmacol., 2014, 9, 194-197. http://dx.doi.org/10.3329/bjp.v9i2.17304

[128] Siratantri, T.; Yogabuana, M.; Olivia, S. An In Vitro Study of Antidiabetic Activity of Sargassum duplicatum and Turbinaria decurens Seaweed. Int. J. Pharm. Sci. Invent. ISSN, 2014, 3(21), 2319-6718.

[129] Kawamura-Konishi, Y.; Watanabe, N.; Saito, M.; Nakajima, N.; Sakaki, T.; Katayama, T.; Enomoto, T. Isolation of a new phlorotannin, a potent inhibitor of carbohydrate-hydrolyzing enzymes, from the brown alga Sargassum patens. J. Agric. Food Chem., 2012, 60(22), 5565-5570. http://dx.doi.org/10.1021/jf300165j PMID: 22594840

[130] Motshakeri, M.; Ebrahimi, M.; Goh, Y.M.; Matanjun, P.; Mohamed, S. Sargassum polycystum reduces hyperglycaemia, dyslipidaemia and oxidative stress via increasing insulin sensitivity in a rat model of type 2 diabetes. J. Sci. Food Agric., 2013, 93(7), 1772-1778. http://dx.doi.org/10.1002/jsfa.5971 PMID: 23208488

[131] Hwang, P.A.; Hung, Y.L.; Tsai, Y.K.; Chien, S.Y.; Kong, Z.L. The brown seaweed Sargassum hemiphyllum exhibits $\alpha$-amylase and $\alpha$-glucosidase inhibitory activity and enhances insulin release in vitro. Cytotechnology, 2015, 67(4), 653-660.

http://dx.doi.org/10.1007/s10616-014-9745-9 PMID: 25344877

[132] Gotama, T.L.; Husni, U.A. Ustadi Antidiabetic activity of Sargassum hystrix extracts in streptozotocin-induced diabetic rats. Prev. Nutr. Food Sci., 2018, 23(3), 189-195. http://dx.doi.org/10.3746/pnf.2018.23.3.189 PMID: 30386746

[133] Chin, Y.X.; Lim, P.E.; Maggs, C.A.; Phang, S.M.; Sharifuddin, Y.; Green, B.D. Anti-diabetic potential of selected Malaysian seaweeds. J. Appl. Phycol., 2015, 27, 2137-2148.

http://dx.doi.org/10.1007/s10811-014-0462-8

[134] Ali, M.Y.; Kim, D.H.; Seong, S.H.; Kim, H.R.; Jung, H.A.; Choi, J.S. $\alpha$-Glucosidase and protein tyrosine phosphatase $1 \mathrm{~b}$ inhibitory activity of plastoquinones from marine brown alga Sargassum serratifolium. Mar. Drugs, 2017, 15(12), 15.

http://dx.doi.org/10.3390/md15120368 PMID: 29194348

[135] Hosokawa, M.; Miyashita, T.; Nishikawa, S.; Emi, S.; Tsukui, T.; Beppu, F.; Okada, T.; Miyashita, K. Fucoxanthin regulates adipocytokine mRNA expression in white adipose tissue of diabetic/obese KK-Ay mice. Arch. Biochem. Biophys., 2010, 504(1), 17-25.

http://dx.doi.org/10.1016/j.abb.2010.05.031 PMID: 20515643

[136] Oh, J.H.; Kim, J.; Lee, Y. Anti-inflammatory and anti-diabetic effects of brown seaweeds in high-fat diet-induced obese mice. Nutr. Res. Pract., 2016, 10(1), 42-48. http://dx.doi.org/10.4162/nrp.2016.10.1.42

PMID:

\section{5}

[137] Tanemura, Y.; Yamanaka-Okumura, H.; Sakuma, M.; Nii, Y.; Taketani, Y.; Takeda, E. Effects of the intake of Undaria pinnatifida (Wakame) and its sporophylls (Mekabu) on postprandial glucose and insulin metabolism. J. Med. Invest., 2014, 61(3-4), 291-297.

http://dx.doi.org/10.2152/jmi.61.291 PMID: 25264047

[138] Yoshinaga, K.; Mitamura, R. Effects of Undaria pinnatifida (Wakame) on postprandial glycemia and insulin levels in humans: a randomized crossover trial. Plant Foods Hum. Nutr., 2019, 74(4), 461-467.

http://dx.doi.org/10.1007/s11130-019-00763-5 PMID: 31418121

[139] Kim, K.J.; Lee, B.Y. Fucoidan from the sporophyll of Undaria pinnatifida suppresses adipocyte differentiation by inhibition of inflammation-related cytokines in 3T3-L1 cells. Nutr. Res., 2012, 32(6), 439-447.

http://dx.doi.org/10.1016/j.nutres.2012.04.003 PMID: 22749180

[140] Maeda, H.; Hosokawa, M.; Sashima, T.; Murakami-Funayama, K.; Miyashita, K. Anti-obesity and anti-diabetic effects of fucoxanthin on diet-induced obesity conditions in a murine model. Mol. Med. Rep., 2009, 2(6), 897-902. http://dx.doi.org/10.3892/mmr_00000189 PMID: 21475918

[141] Maeda, H.; Hosokawa, M.; Sashima, T.; Funayama, K.; Miyashita, K. Fucoxanthin from edible seaweed, Undaria pinnatifida, shows antiobesity effect through UCP1 expression in white adipose tissues. Biochem. Biophys. Res. Commun., 2005, 332(2), 392-397.

http://dx.doi.org/10.1016/j.bbrc.2005.05.002 PMID: 15896707

[142] Jung, H.A.; Islam, M.N.; Lee, C.M.; Jeong, H.O.; Chung, H.Y.; Woo, H.C.; Choi, J.S. Promising antidiabetic potential of fucoxanthin isolated from the edible brown algae Eisenia bicyclis and Undaria pinnatifida. Fish. Sci., 2012, 78(6), 1321-1329. http://dx.doi.org/10.1007/s12562-012-0552-y

[143] Koirala, P.; Jung, H.A.; Choi, J.S. Recent advances in pharmacological research on Ecklonia species: a review. Arch. Pharm. Res., 2017, 40(9), 981-1005.

http://dx.doi.org/10.1007/s12272-017-0948-4 PMID: 28840539

[144] Manandhar, B.; Paudel, P.; Seong, S.H.; Jung, H.A.; Choi, J.S. Characterizing eckol as a therapeutic aid: a systematic review. Mar. Drugs, 2019, 17(6), 17.

http://dx.doi.org/10.3390/md17060361 PMID: 31216636

[145] Saravana, P.S.; Cho, Y.J.; Park, Y.B.; Woo, H.C.; Chun, B.S. Structural, antioxidant, and emulsifying activities of fucoidan from Saccharina japonica using pressurized liquid extraction. Carbohydr. Polym., 2016, 153, 518-525. http://dx.doi.org/10.1016/j.carbpol.2016.08.014 PMID: 27561524

[146] Ganesan, K.; Xu, B. Anti-diabetic effects and mechanisms of dietary polysaccharides. Molecules, 2019, 24(14), 24. http://dx.doi.org/10.3390/molecules24142556 PMID: 31337059

[147] Yende, S.R.; Harle, U.N.; Chaugule, B.B. Therapeutic potential and health benefits of Sargassum species. Pharmacogn. Rev., 2014, 8(15), 1-7.

http://dx.doi.org/10.4103/0973-7847.125514 PMID: 24600190

[148] Motshakeri, M.; Ebrahimi, M.; Goh, Y.M.; Othman, H.H.; Hair-Bejo, M.; Mohamed, S. Effects of brown seaweed (Sargassum polycystum) extracts on kidney, liver, and pan- 
creas of type 2 diabetic rat model. Evidence-based Complement. Evid. Based Complement. Alternat. Med., 2014, 2014, 379407.

http://dx.doi.org/10.1155/2014/379407 PMID: 24516503

[149] McHugh, D.J. Seaweeds uses as Human Foods. In: $A$ Guide to the Seaweed Industry; FAO Fisheries Technical Paper 441: Rome, 2003; p. 105.

[150] Wang, L.; Park, Y.J.; Jeon, Y.J.; Ryu, B.M. Bioactivities of the edible brown seaweed, Undaria pinnatifida: a review. Aquaculture, 2018, 495, 873-880.

http://dx.doi.org/10.1016/j.aquaculture.2018.06.079

[151] Yoshinaga, K.; Nakai, Y.; Izumi, H.; Nagaosa, K.; Ishijima, T.; Nakano, T.; Abe, K. Oral administration of edible seaweed Undaria pinnatifida (Wakame) modifies glucose and lipid metabolism in rats: a DNA microarray analysis. Mol. Nutr. Food Res., 2018, 62(12), e1700828.

http://dx.doi.org/10.1002/mnfr.201700828 PMID: 29663642

[152] Paxman, J.R.; Richardson, J.C.; Dettmar, P.W.; Corfe, B.M. Alginate reduces the increased uptake of cholesterol and glucose in overweight male subjects: a pilot study. $\mathrm{Nu}$ tr. Res., 2008, 28(8), 501-505.

http://dx.doi.org/10.1016/j.nutres.2008.05.008 PMID: 19083452

[153] Sharifuddin, Y.; Chin, Y.X.; Lim, P.E.; Phang, S.M. Potential bioactive compounds from seaweed for diabetes management. Mar. Drugs, 2015, 13(8), 5447-5491. http://dx.doi.org/10.3390/md13085447 PMID: 26308010

[154] Celikler, S.; Tas, S.; Vatan, O.; Ziyanok-Ayvalik, S.; Yildiz, G.; Bilaloglu, R. Anti-hyperglycemic and antigenotoxic potential of Ulva rigida ethanolic extract in the experimental diabetes mellitus. Food Chem. Toxicol., 2009, 47(8), 1837-1840.

http://dx.doi.org/10.1016/j.fct.2009.04.039 PMID: 19422873

[155] Islam, M.N.; Choi, S.H.; Moon, H.E.; Park, J.J.; Jung, H.A.; Woo, M.H.; Woo, H.C.; Choi, J.S. The inhibitory activities of the edible green alga Capsosiphon fulvescens on rat lens aldose reductase and advanced glycation end products formation. Eur. J. Nutr., 2014, 53(1), 233-242. http://dx.doi.org/10.1007/s00394-013-0521-y PMID: 23575770

[156] Sun, Z.; Peng, X.; Liu, J.; Fan, K.W.; Wang, M.; Chen, F. Inhibitory effects of microalgal extracts on the formation of advanced glycation endproducts (AGEs). Food Chem., 2010, 120, 261-267.

http://dx.doi.org/10.1016/j.foodchem.2009.10.018

[157] Sharma, B.R.; Rhyu, D.Y. Anti-diabetic effects of Caulerpa lentillifera: stimulation of insulin secretion in pancreatic $\beta$-cells and enhancement of glucose uptake in adipocytes. Asian Pac. J. Trop. Biomed., 2014, 4(7), 575-580. http://dx.doi.org/10.12980/APJTB.4.2014APJTB-2014-00 91 PMID: 25183280

[158] Sharma, B.R.; Kim, H.J.; Rhyu, D.Y. Caulerpa lentillifera extract ameliorates insulin resistance and regulates glucose metabolism in C57BL/KsJ-db/db mice via PI3K/AKT signaling pathway in myocytes. J. Transl. Med., 2015, 13, 62 . http://dx.doi.org/10.1186/s12967-015-0412-5 PMID: 25889508

[159] Granados, R.U.G.; Aguilar, F.A.; Martínez, M.G.; LaraIsassi, G. Sub-chronic treatment in diabetic mice with Caulerpa sertularioides (Chlorophyta) and Spyridia filamentosa(Rhodophyta). Hidrobiologica, 2016, 26, 269-276. http://dx.doi.org/10.24275/uam/izt/dcbs/hidro/2016v26n2/ DeLara
[160] Kumar, J.G.S.; Umamaheswari, S.; Kavimani, S.; Ilavarasan, R. Pharmacological potential of green algae Caulerpa: a review. Int. J. Pharm. Sci. Res., 2019, 10, 1014.

http://dx.doi.org/10.13040/IJPSR.0975-8232.10(3).1014-2 4

[161] Sun, Z.; Liu, J.; Zeng, X.; Huangfu, J.; Jiang, Y.; Wang, M.; Chen, F. Astaxanthin is responsible for antiglycoxidative properties of microalga Chlorella zofingiensis. Food Chem., 2011, 126(4), 1629-1635.

http://dx.doi.org/10.1016/j.foodchem.2010.12.043 PMID: 25213937

[162] BelHadj, S.; Hentati, O.; Elfeki, A.; Hamden, K. Inhibitory activities of Ulva lactuca polysaccharides on digestive enzymes related to diabetes and obesity. Arch. Physiol. Biochem., 2013, 119(2), 81-87.

http://dx.doi.org/10.3109/13813455.2013.775159 PMID: 23638862

[163] Harnedy, P.A.; FitzGerald, R.J. In vitro assessment of the cardioprotective, anti-diabetic and antioxidant potential of Palmaria palmata protein hydrolysates. J. Appl. Phycol., 2013, 25, 1793-1803.

http://dx.doi.org/10.1007/s10811-013-0017-4

[164] Nwosu, F.; Morris, J.; Lund, V.A.; Stewart, D.; Ross, H.A.; McDougall, G.J. Anti-proliferative and potential anti-diabetic effects of phenolic-rich extracts from edible marine algae. Food Chem., 2011, 126(3), 1006-1012. http://dx.doi.org/10.1016/j.foodchem.2010.11.111

[165] Shi, D.; Guo, S.; Jiang, B.; Guo, C.; Wang, T.; Zhang, L.; Li, J. HPN, a synthetic analogue of bromophenol from red alga Rhodomela confervoides: synthesis and anti-diabetic effects in C57BL/KsJ-db/db mice. Mar. Drugs, 2013, 11(2), 350-362.

http://dx.doi.org/10.3390/md11020350 PMID: 23364683

[166] Kim, K.Y.; Nam, K.A.; Kurihara, H.; Kim, S.M. Potent $\alpha-$ glucosidase inhibitors purified from the red alga Grateloupia elliptica. Phytochemistry, 2008, 69(16), 2820-2825. http://dx.doi.org/10.1016/j.phytochem.2008.09.007 PMID: 18951591

[167] Wang, W.; Okada, Y.; Shi, H.; Wang, Y.; Okuyama, T. Structures and aldose reductase inhibitory effects of bromophenols from the red alga Symphyocladia latiuscula. $J$. Nat. Prod., 2005, 68(4), 620-622.

http://dx.doi.org/10.1021/np040199j PMID: 15844965

[168] Yang, T.H.; Yao, H.T.; Chiang, M.T. Red algae (Gelidium amansii) reduces adiposity via activation of lipolysis in rats with diabetes induced by streptozotocin-nicotinamide. Yao Wu Shi Pin Fen Xi, 2015, 23(4), 758-765.

http://dx.doi.org/10.1016/j.jfda.2015.06.003 PMID: 28911493

[169] Kurihara, H.; Mitani, T.; Kawabata, J.; Takahashi, K. Inhibitory Potencies of Bromophenols from Rhodomelaceae Algae against $\alpha$-Glucosidase Activity. Fish. Sci., 1999, 65, 300-303. http://dx.doi.org/10.2331/fishsci.65.300

[170] Kim, K.Y.; Nguyen, T.H.; Kurihara, H.; Kim, S.M. $\alpha$-glucosidase inhibitory activity of bromophenol purified from the red alga Polyopes lancifolia. J. Food Sci., 2010, 75(5), H145-H150.

http://dx.doi.org/10.1111/j.1750-3841.2010.01629.x PMID: 20629879

[171] Shi, D.; Xu, F.; He, J.; Li, J.; Fan, X.; Han, L. Inhibition of bromophenols against PTP1B and anti-hyperglycemic effect of Rhodomela confervoides extract in diabetic rats. Chin. Sci. Bull., 2008, 53(16), 2476-2479. 
[172] Qin, J.; Su, H.; Zhang, Y.; Gao, J.; Zhu, L.; Wu, X.; Pan, $\mathrm{H}$.; Li, X. Highly brominated metabolites from marine red alga Laurencia similis inhibit protein tyrosine phosphatase 1B. Bioorg. Med. Chem. Lett., 2010, $20(23), 7152-7154$. http://dx.doi.org/10.1016/j.bmcl.2010.08.144 PMID: 20961755

[173] Lu, D.-Y.; Che, J.-Y.; Yarla, N.S.; Wu, H.-Y.; Lu, T.-R.; Xu, B.; Wu, S.-Y.; Ding, J.; Lu, Y.; Zhu, H. Type 2 Diabetes Treatment and Drug Development Study. Open Diabetes J., 2018, 8, 22-33. http://dx.doi.org/10.2174/1876524601808010022

[174] Gray, A.; Threlkeld, R.J. Nutritional recommendations for individuals with diabetes. In: Endotext; Feingold, K.R.; Anawalt, B.; Boyce, A.; Chrousos, G.; de Herder, W.W.; Dungan, K.; Grossman, A.; Hershman, J.M.; Hofland, J.; Kaltsas, G.; Koch, C.; Kopp, P.; Korbonits, M.; McLachlan, R.; Morley, J.E.; New, M.; Purnell, J.; Singer, F.; Stratakis, C.A.; Trence, D.L.; Wilson, D.P., Eds.; MDText.com, Inc.: South Dartmouth (MA), 2000; p. 54. PMID: 25905243

[175] Ley, S.H.; Hamdy, O.; Mohan, V.; Hu, F.B. Prevention and management of type 2 diabetes: dietary components and nutritional strategies. Lancet, 2014, 383(9933), 1999-2007.

http://dx.doi.org/10.1016/S0140-6736(14)60613-9 PMID: 24910231

[176] Tiwari, P. Recent trends in therapeutic approaches for diabetes management: a comprehensive update. J. Diabetes Res., 2015, 2015, 340838. http://dx.doi.org/10.1155/2015/340838 PMID: 26273667

[177] Campbell, R.K. Type 2 diabetes: where we are today: an overview of disease burden, current treatments, and treatment strategies. J. Am. Pharm. Assoc., 2009, 49 (49 Suppl. 1), S3-S9.

http://dx.doi.org/10.1331/JAPhA.2009.09077 PMID: 19801365

[178] Brown, A.L.; Lane, J.; Coverly, J.; Stocks, J.; Jackson, S.; Stephen, A.; Bluck, L.; Coward, A.; Hendrickx, H. Effects of dietary supplementation with the green tea polyphenol epigallocatechin-3-gallate on insulin resistance and associated metabolic risk factors: randomized controlled trial. Br. J. Nutr., 2009, 101(6), 886-894.

http://dx.doi.org/10.1017/S0007114508047727 PMID: 18710606

[179] Xiao, J.B.; Högger, P. Dietary polyphenols and type 2 diabetes: current insights and future perspectives. Curr. Med. Chem., 2015, 22(1), 23-38.

http://dx.doi.org/10.2174/0929867321666140706130807 PMID: 25005188

[180] Scalbert, A.; Manach, C.; Morand, C.; Rémésy, C.; Jiménez, L. Dietary polyphenols and the prevention of diseases. Crit. Rev. Food Sci. Nutr., 2005, 45(4), 287-306. http://dx.doi.org/10.1080/1040869059096

PMID: 16047496

[181] Guasch-Ferré, M.; Merino, J.; Sun, Q.; Fitó, M.; Salas-Salvadó, J. Dietary Polyphenols, Mediterranean Diet, Prediabetes, and Type 2 Diabetes: A Narrative Review of the Evidence. Oxid. Med. Cell. Longev., 2017, 2017, 6723931. PMID: 28883903

[182] Rout, S.P.; Chowdary, K.A.; Kar, D.M.; Das, L. Plants as source of novel anti-diabetic drug: present scenario and future perspectives. Curr. Trends Biotechnol. Pharm., 2009, 3,614 . 